Article

\title{
Iron(III) Azadiphenolate Compounds in a New Family of Spin Crossover Iron(II)-Iron(III) Mixed-Valent Complexes
}

\author{
Wasinee Phonsri ${ }^{1}{ }^{(\mathbb{C}}$, David S. Macedo ${ }^{1}$, Barnaby A. I. Lewis ${ }^{1,2}$, Declan F. Wain ${ }^{1}{ }^{(1)}$ and \\ Keith S. Murray ${ }^{1, *(D)}$ \\ 1 School of Chemistry, 17 Rainforest Walk, Monash University, Clayton, VIC 3800, Australia; \\ wasinee.phonsri@monash.edu (W.P.); David.Macedo@csiro.au (D.S.M.); B.Lewis@warwick.ac.uk (B.A.I.L.); \\ dfwai1@student.monash.edu (D.F.W.) \\ 2 Department of Chemistry, University of Warwick, Coventry CV4 7AL, UK \\ * Correspondence: Keith.Murray@monash.edu; Tel.: +613-9905-4512; Fax: +613-9905-4597
}

Received: 21 May 2019; Accepted: 6 June 2019; Published: 12 June 2019

Abstract: A new family of mixed valent, double salt spin crossover compounds containing anionic $\mathrm{Fe}^{\mathrm{III}}$ and cationic $\mathrm{Fe}^{\mathrm{II}}$ compounds i.e., $\left.\left[\mathrm{Fe}^{\mathrm{II}}\left\{(\mathrm{pz})_{3} \mathrm{CH}\right\}_{2}\right]\left[\mathrm{Fe}^{\mathrm{III}}(\mathrm{azp})_{2}\right]_{2} \cdot 2 \mathrm{H}_{2} \mathrm{O}(4),\left[\mathrm{Fe}^{\mathrm{II}}(\mathrm{TPPZ})_{2}\right]\left[\mathrm{Fe}^{\mathrm{III}}(\mathrm{azp})_{2}\right]_{2}\right] \cdot \mathrm{H}_{2} \mathrm{O}$ (5) and $\left.\left[\mathrm{Fe}^{\mathrm{II}}(\mathrm{TPPZ})_{2}\right]\left[\mathrm{Fe}^{\mathrm{III}}(\mathrm{azp})_{2}\right]_{2}\right] \cdot \mathrm{H}_{2} \mathrm{O} \cdot 3 \mathrm{MeCN}(6)$ (where $(\mathrm{pz})_{3} \mathrm{CH}=$ tris-pyrazolylmethane, TPPZ $=2,3,5,6$, tetrapyridylpyrazine and azp ${ }^{2-}=$ azadiphenolato) has been synthesized and characterised. This is the first time that the rare anionic spin crossover species, $\left[\mathrm{Fe}^{\mathrm{III}}(\operatorname{azp})_{2}\right]^{-}$, has been used as an anionic component in double salts complexes. Single crystal structures and magnetic studies showed that compound 6 exhibits a spin transition relating to one of the $\mathrm{Fe}^{\mathrm{III}}$ centres of the constituent $\mathrm{Fe}^{\mathrm{II}}$ and $\mathrm{Fe}^{\mathrm{III}}$ sites. Crystal structures of the anionic and cationic precursor complexes were also analysed and compared to the double salt products thus providing a clearer picture for future crystal design in double spin crossover materials. We discuss the effects that the solvent and counterion had on the crystal packing and spin crossover properties.

Keywords: spin crossover; mixed valent; double salts; mixed $\mathrm{Fe}^{\mathrm{II}}-\mathrm{Fe}^{\mathrm{III}}$; magnetic properties; crystal structures

\section{Introduction}

We are exploring hybrid (bifunctional) molecular materials containing, for example, (spin crossover (A)/spin crossover (B)) centres i.e., double spin crossover species. There are two broad approaches to designing such materials that contain two different spin crossover (SCO) sites. One is to graft/join two SCO metallo sites via covalent bonding, the other is to make ionic double SCO materials in which the cationic metal complex contains one SCO site while the anion contains another SCO site. In regard to the latter approach, while there are many cationic $\mathrm{Fe}^{\mathrm{II}}$ or $\mathrm{Fe}^{\mathrm{III}} \mathrm{SCO}$ compounds known [1-4], the anionic SCO species are limited mainly to $\mathrm{Fe}^{\mathrm{III}}$ and to tridentate ligands of the thiosemicarbazonato (X-sal-thsa ${ }^{2-}, \mathrm{X}=$ halide, $\mathrm{NO}_{2}$ ) or azadiphenolato (azp ${ }^{2-}$ ) types, in 6-coordinate compounds of type $\left[\mathrm{Fe}(\mathrm{X} \text {-thsa })_{2}\right]^{-}[5-7]$ or $\left.\mathrm{Fe}(\mathrm{azp})_{2}\right]^{-}[8,9]$.

Unknown at the outset was the effect that ionic interactions or intermolecular interactions might have on the spin crossover properties of the individual sites, not to mention the effects that two SCO sites might have on each other. There is, however, precedence for the isolation of crystalline hybrid double salts in which the cation is a SCO site while the anion has a separate function such as electron transfer; e.g., [Fe(qsal $\left.)_{2}\right]\left[\mathrm{Ni}(\mathrm{dmit})_{2}\right][10-12]$ (qsal $=(\mathrm{N}-8$-quinolyl)-5-X-salicylaldiminate and $\mathrm{dmit}=2$-thioxo-1,3-dithiole-4,5-dithio-lato $)$, 
[Fe(qsal) $\left.)_{2}\right]\left[\mathrm{Ni}(\mathrm{mnt})_{2}\right]$ [13] (mnt = maleonitriledithiolate) or a paramagnetic function e.g., $\left[\mathrm{Fe}^{\mathrm{II}}\left\{(\mathrm{pz})_{3} \mathrm{CH}\right\}_{2}\right]_{3}\left[\mathrm{Fe}^{\mathrm{III}}\left(\mathrm{C}_{2} \mathrm{O}_{4}\right)_{3}\right]_{2} \cdot 20 \mathrm{H}_{2} \mathrm{O}$ [14] and $\left[\mathrm{Fe}(\mathrm{dppOH})_{2}\right]_{3}\left[\mathrm{PMo}_{12} \mathrm{O}_{40}\right]_{2}$ [15] (dppOH = 2,6-di(pyrazol-1-yl)-4-(hydroxymethyl)pyridine). We also recently described one of the ways that the double SCO salt reaction design can lead, surprisingly, to other products, often with very interesting properties, viz. formation of neutral, heteroleptic SCO complexes such as [Fe $\mathrm{Fe}^{\mathrm{III}}$ (qsal)(thsa)] [16].

In this work, we focus on mixed valence states of iron(II) and iron(III) which can allow access to several electronic states as a result of spin-crossover in both the $\mathrm{Fe}^{\mathrm{II}}$ and $\mathrm{Fe} \mathrm{eII}^{\mathrm{II}}$ centres. Furthermore, supramolecular assemblies in the structures of such materials can produce a cooperative effect between the spin-crossover sites [17]. To date, much of the work in this area has involved only two systems, $\left[\mathrm{Fe}^{\mathrm{II}} \mathrm{Lx}_{\mathrm{X}}\right]\left[\mathrm{Fe}^{\mathrm{III}}(\mathrm{dipic})_{2}\right]_{\mathrm{Y}}(\mathrm{L}$ = 1,10-phenanthroline [18], 2,2'-bipyridine [19] $(X=3, Y=2), L=$ terpyridine [20] $(X=2, Y=2)$, and $L=$ $2,3,5,6$, tetrapyridylpyrazine [20] $(X=2, Y=1)$, dipic ${ }^{2-}=2,6$-pyridinedicarboxylate $)$ and a homochiral assembly of the chiral species $\left[\mathrm{Fe}^{\mathrm{II}} \mathrm{H}_{3} \mathrm{~L}\right]\left[\mathrm{Fe}^{\mathrm{III}} \mathrm{L}\right] \mathrm{X}_{2}$ where $\mathrm{H}_{3} \mathrm{~L}$ and derivatives denote a hexadentate $\mathrm{N}_{6}$ tripod ligand containing three imidazole groups [17,21-24].

Here, we look in some detail at the $\left[\mathrm{Fe}^{\mathrm{III}}(\mathrm{azp})_{2}\right]^{-}$complex which we use as an anionic starter material (Figure 1). The potassium salt, $\mathrm{K}\left[\mathrm{Fe}(\operatorname{azp})_{2}\right]$, was reported [9] to have a dimer structure involving $\mathrm{K}^{+}$bridging, linked into chains, but without any physical properties reported. It was used, in metathetic reactions, to make $\left(\mathrm{Me}_{4} \mathrm{~N}\right)\left[\mathrm{Fe}(\operatorname{azp})_{2}\right],\left(\mathrm{Ph}_{4} \mathrm{P}\right)\left[\mathrm{Fe}(\mathrm{azp})_{2}\right]$ and $\left(\mathrm{Bu}_{4} \mathrm{~N}\right)\left[\mathrm{Fe}(\operatorname{azp})_{2}\right]$ whose structural and magnetic properties revealed SCO for the $\mathrm{Me}_{4} \mathrm{~N}$ and $\mathrm{Bu}_{4} \mathrm{~N}$ salts and high spin (HS) behaviour for the $\mathrm{Ph}_{4} \mathrm{P}$ salt, somewhat unexpected observations for a $\mathrm{Fe}^{\mathrm{III}} \mathrm{N}_{2} \mathrm{O}_{4}$ chromophore that would normally be expected to lead to high spin (HS) behaviour.

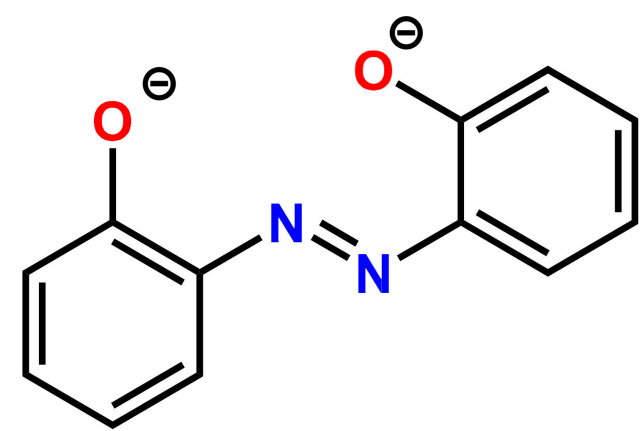

azp $^{2-}$

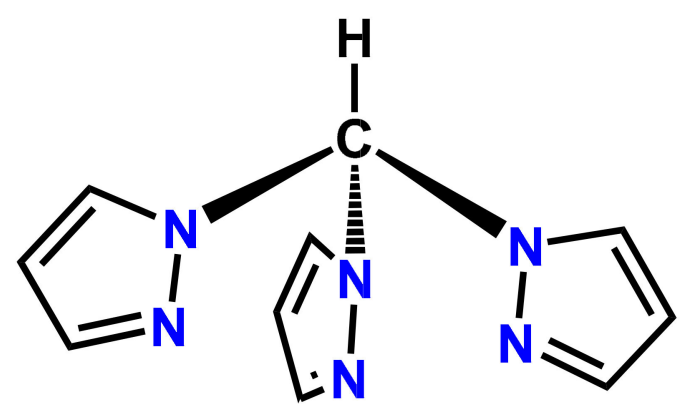

$(\mathrm{pz})_{3} \mathrm{CH}$<smiles>c1ccc(-c2nc(-c3ccccn3)c(-c3ccccn3)nc2-c2ccccn2)nc1</smiles>

TPPZ

Figure 1. Molecular structures of ligands used in this work. TPPZ tetrapyridylpyrazine.

For the cationic precursor, we selected $\left[\mathrm{Fe}^{\mathrm{II}}\left\{(\mathrm{pz})_{3} \mathrm{CH}\right\}_{2}\right]^{2+}$ and $\left[\mathrm{Fe}^{\mathrm{II}}(\mathrm{TPPZ})_{2}\right]^{2+}$. Several iron(II) complexes of tris-pyrazolylmethane, $(\mathrm{pz})_{3} \mathrm{CH}$, ligands and the ligands derivatives are known [25-27]. Salts of $\left[\mathrm{Fe}^{\mathrm{II}}\left\{(\mathrm{pz})_{3} \mathrm{CH}\right\}_{2}\right]^{2+}$ are low-spin at room temperature but can undergo thermal spin-transitions 
on heating $[28,29]$. On the other hand, the multi-ring heterocycle $2,3,5,6$, tetrapyridylpyrazine (TPPZ) is less known in the iron(II) spin crossover area. Although, the $\mathrm{N}_{6}$ donor set that the ligand provides may result in spin crossover with iron(II), up to date, only the X-ray structures of the low-spin (LS) [Fe(TPPZ) $\left.)_{2}\right]\left(\mathrm{ClO}_{4}\right)_{2} \cdot \mathrm{CH}_{3} \mathrm{CN} \cdot \mathrm{H}_{2} \mathrm{O}$ [30] and [Fe(TPPZ) $\left.)_{2}\right]\left[\mathrm{Fe}(\mathrm{NCS})_{4}\right]$ [31], and the high-spin (HS) $\left[\mathrm{Fe}(\mathrm{TPPZ}) \mathrm{Cl}_{2}\right.$ ] have been reported [30]. For mixed valent state systems, the crystal structure of $\left\{\left[\mathrm{Fe}^{\mathrm{II}}(\mathrm{TPPZ})_{2}\right]\left[(\text { dipic })_{2} \mathrm{Fe}^{\mathrm{III}}\right]_{3}\right\} \cdot\left(\mathrm{H}_{3} \mathrm{O}\right)$ was characterised, however, the magnetic properties of the compound has not been investigated [20]. Given that the 2,6-di(pyrazol-1-yl)pyrazine and derivatives have been found to induce a spin transition in several examples of iron(II) complexes [32,33], we decided to investigate the complex formation between this metal ion and TPPZ.

Our aim was to form novel compounds by combining, ionically, possible spin crossover components using precursor complexes 1, $\mathbf{2}$ and $\mathbf{3}$ (see below). For the first time, we have succeeded in making mixed valent state double salts between $\left[\mathrm{Fe}^{\mathrm{III}}(\mathrm{azp})_{2}\right]^{-}$anionic compounds with cationic $\left[\mathrm{Fe}^{\mathrm{II}} \mathrm{L}\right]^{2+}$ complexes i.e., $\left.\left[\mathrm{Fe}^{\mathrm{II}}\left\{(\mathrm{pz})_{3} \mathrm{CH}\right\}_{2}\right]\left[\mathrm{Fe}^{\mathrm{III}}(\mathrm{azp})_{2}\right]_{2} \cdot 2 \mathrm{H}_{2} \mathrm{O}(4),\left[\mathrm{Fe}^{\mathrm{II}}(\mathrm{TPPZ})_{2}\right]\left[\mathrm{Fe}^{\mathrm{III}}(\mathrm{azp})_{2}\right]_{2}\right] \cdot \mathrm{H}_{2} \mathrm{O}(5)$ and $\left.\left[\mathrm{Fe}^{\mathrm{II}}(\mathrm{TPPZ})_{2}\right]\left[\mathrm{Fe}^{\mathrm{III}}(\operatorname{azp})_{2}\right]_{2}\right] \cdot \mathrm{H}_{2} \mathrm{O} \cdot 3 \mathrm{MeCN}(6)$. The spin states on the $\mathrm{Fe}^{\mathrm{II}}$ and $\mathrm{Fe}^{\mathrm{III}}$ sites are shown to be largely trapped with little evidence, thus far, for SCO occurring as a function of temperature on either the $\mathrm{Fe}^{\mathrm{II}}$ or $\mathrm{Fe}^{\mathrm{III}}$ sites. The structures and properties are described below with emphasis on a detailed discussion on crystal packing and intermolecular interactions that are important, along with the ligand field created by the donor atoms, in determining spin states on the $\mathrm{Fe}^{\mathrm{III}}, \mathrm{d}^{5}$, and the $\mathrm{Fe}^{\mathrm{II}}$, $\mathrm{d}^{6}$, centres.

\section{Results and Discussion}

\subsection{Preparation of Precursor Materials}

For the synthesis of anionic precursor complexes, $\left[\mathrm{Fe}^{\mathrm{III}}(\operatorname{azp})_{2}\right]^{-}$, we followed the method of Takahashi et al. [9] in which $\mathrm{FeCl}_{3}, \mathrm{KOH}$ and $\mathrm{H}_{2}$ azp were reacted in ethanol in a 1:4:2 mol ratio, the black product being recrystallised from a $\mathrm{MeOH} / \mathrm{Et}_{2} \mathrm{O}$ solvent mixture yielding $\mathrm{K}\left[\mathrm{Fe}^{\mathrm{III}}(\text { azp })_{2}\right] \cdot\left(\mathrm{H}_{2} \mathrm{O}\right)_{3} \cdot \mathrm{MeOH}$ (1). $\left[\mathrm{Fe}^{\mathrm{II}}\left\{(\mathrm{pz})_{3} \mathrm{CH}\right\}_{2}\right]\left[\mathrm{ClO}_{4}\right]_{2}$ (2) was used as a cationic $\left[\mathrm{Fe}^{\mathrm{II}}\left\{(\mathrm{pz})_{3} \mathrm{CH}\right\}_{2}\right]^{2+}$ precursor and was prepared using a previously reported procedure [28]. The pink powder of 2 was obtained from a reaction of the tris(pyrazolyl)methane, $(\mathrm{pz})_{3} \mathrm{CH}$, ligand and $\mathrm{Fe}\left(\mathrm{ClO}_{4}\right)_{3} \cdot \mathrm{nH}_{2} \mathrm{O}$ in a mixture of methanol and acetone solvents. Alternatively, the same pink product could also be obtained from a reaction of $(\mathrm{pz})_{3} \mathrm{CH}$ and $\mathrm{Fe}\left(\mathrm{ClO}_{4}\right)_{2} \cdot 4 \mathrm{H}_{2} \mathrm{O}$ in acetonitrile $(\mathrm{MeCN})$ as solvent. A further cationic $\mathrm{Fe}(\mathrm{II})$ precursor, $\left[\mathrm{Fe}^{\mathrm{II}}(\mathrm{TPPZ})_{2}\right]^{2+}$, was made. In this case, single crystals of an unexpected double salt $\left[\mathrm{Fe}^{\mathrm{II}}(\mathrm{TPPZ})_{2}\right]\left[\left(\mathrm{Fe}^{\mathrm{III}} \mathrm{Cl}_{3}\right)_{2} \mathrm{O}\right] \cdot 2 \mathrm{MeCN}$ (3) were obtained from diethyl ether diffusion into the concentrated $\mathrm{MeOH}$ and $\mathrm{MeCN}$ filtrate obtained upon reaction of $\mathrm{FeCl}_{2} \cdot 4 \mathrm{H}_{2} \mathrm{O}$ with TPPZ. Notably, although according to the PXRD results, $\mathrm{K}\left[\mathrm{Fe}^{\mathrm{III}}(\mathrm{azp})_{2}\right] \cdot\left(\mathrm{H}_{2} \mathrm{O}\right)_{3} \cdot \mathrm{MeOH}$ and $\left[\mathrm{Fe}^{\mathrm{II}}(\mathrm{TPPZ})_{2}\right]\left[\left(\mathrm{Fe}^{\mathrm{III}} \mathrm{Cl}_{3}\right)_{2} \mathrm{O}\right] \cdot 2 \mathrm{MeCN}$ were not the only phases found in bulk sample of $\mathbf{1}$ and 3, the sample were still able to be used to attempt to prepare double salt spin crossover materials, as the aim here was to synthesize $\left[\mathrm{Fe}^{\mathrm{III}}(\operatorname{azp})_{2}\right]^{-}$and $\left[\mathrm{Fe}^{\mathrm{II}}(\mathrm{TPPZ})_{2}\right]^{2+}$ precursors, respectively.

\subsection{Attempted Preparation of 'Double Spin Crossover' Materials}

Suitable crystals used for single crystal X-ray diffraction of $\left[\mathrm{Fe}^{\mathrm{II}}\left\{(\mathrm{pz})_{3} \mathrm{CH}\right\}_{2}\right]\left[\mathrm{Fe}^{\mathrm{III}}(\mathrm{azp})_{2}\right]_{2} \cdot 2 \mathrm{H}_{2} \mathrm{O}(4)$ and $\left[\mathrm{Fe}^{\mathrm{II}}(\mathrm{TPPZ})_{2}\right]\left[\mathrm{Fe}^{\mathrm{III}}(\mathrm{azp})_{2}\right]_{2} \cdot \mathrm{H}_{2} \mathrm{O}(5)$ were obtained by dissolving the cationic and anionic precursors in a mixture of dimethylformamide and water, and heating in a sealed vial. Unfortunately, despite great efforts, pure bulk samples of compound 4 and 5 were not obtained. However, a homogeneous sample of crystals of $\left[\mathrm{Fe}^{\mathrm{II}}(\mathrm{TPPZ})_{2}\right]\left[\mathrm{Fe}^{\mathrm{III}}(\operatorname{azp})_{2}\right]_{2} \cdot \mathrm{H}_{2} \mathrm{O} \cdot 3 \mathrm{MeCN}(6)$ was obtained from re-crystallization of compound 5 in $\mathrm{MeCN}$.

\subsection{Structural Analysis for Anionic Precursor Materials (Compound 1)}

In contrast to the crystalline solvate obtained by Takahashi et al., $\mathrm{K}\left[\mathrm{Fe}(\mathrm{azp})_{2}\right] \cdot \mathrm{MeOH} \cdot \mathrm{Et}_{2} \mathrm{O}$ (1-ref) [9], we obtained a different solvate viz. $\mathrm{K}\left[\mathrm{Fe}^{\mathrm{III}}(\mathrm{azp})_{2}\right] \cdot\left(\mathrm{H}_{2} \mathrm{O}\right)_{3} \cdot \mathrm{MeOH}(\mathbf{1})$, possibly because of water ingress 
in the present case. There are similarities and differences in the structures of these two solvates. 1-ref crystallizes in the triclinic space group $P \overline{1}$ while the crystal system of 1 is monoclinic, $P 2_{1} / n$ (see Table S1). Both 1-ref and 1 contain the bis-mer-tridentate $\mathrm{Fe}^{\mathrm{III}}(\mathrm{azp})^{2-}$ anion with a potassium ion close by, but with different bonding interactions between them. The asymmetric units of 1-ref and $\mathbf{1}$ are shown in Figure 2. The Fe-donor atom distances are different in the two cases, particularly in the case of the Fe-N distances, those for 1-ref being high-spin Fe $\mathrm{Fe}^{\mathrm{III}}$ in character $(\mathrm{Fe}-\mathrm{O}=1.89-1.97$ and $\mathrm{Fe}-\mathrm{N}=$ 1.92-2.10 $\AA$ ) while those for 1 (Fe-O = 1.88-1.93 and Fe-N = 1.87-1.92 $\AA$ ) being typical of low spin $\mathrm{Fe}^{\mathrm{III}}$, at $123 \mathrm{~K}$ (Table S2). The values of the octahedral distortion parameters, $\Sigma$ and $\Theta$, support these spin state assignments. Notably, apart from the Fe-L bond lengths, octahedral distortion parameters that have been used to define the degree of octahedral distortion $\Sigma$ and $\Theta$, mainly in Fe ${ }^{\mathrm{II}} \mathrm{N}_{6}$ donor sets $[34,35]$, are also helpful in defining spin states of the metal centres here. $\Sigma$, a structural parameter, is defined as the sum of the deviations (from 90 $0^{\circ}$ ) of the 12 cis-angles in the coordination sphere. While $\Theta$, a distortion parameter, is defined as the deviation of the L-Fe-L angle measured on the projection of the two triangular faces of the octahedron projected along its pseudo-threefold axes on the medium plane containing the metal ion from $60^{\circ}[34,35]$.

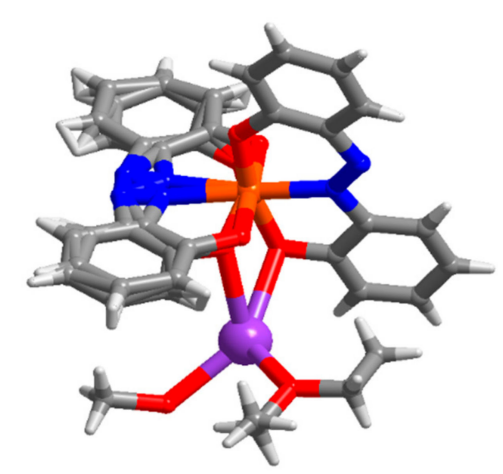

(a)

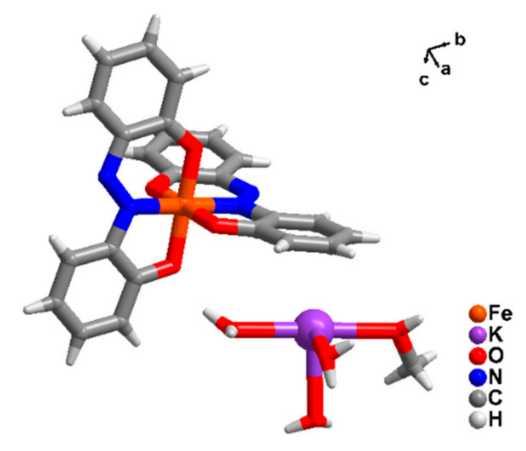

(b)

Figure 2. The asymmetric unit of (a) $\mathrm{K}\left[\mathrm{Fe}(\mathrm{azp})_{2}\right] \cdot \mathrm{MeOH} \cdot \mathrm{Et}_{2} \mathrm{O}$ (1-ref) from ref [9] and (b) $\mathrm{K}\left[\mathrm{Fe}^{\mathrm{III}}(\mathrm{azp})_{2}\right] \cdot\left(\mathrm{H}_{2} \mathrm{O}\right)_{3} \cdot \mathrm{MeOH}(\mathbf{1})$ from this work.

In the case of 1-ref, pairs of [Fe(azp $\left.)_{2}\right]^{-}$anions were bridged by $\mathrm{K}^{+}$ions via $\mathrm{Fe}-\mathrm{O}-\mathrm{K}-\mathrm{O}-\mathrm{Fe}-\mathrm{K}-\mathrm{O}-\sim 90^{\circ}$ phenolate interactions (Figure S1a). Whereas in 1, these O-bridging interactions are absent and the $\mathrm{K}^{+}$ ions are best described as forming $\eta_{4}$ interactions to one of the aromatic rings of neighbouring $\left[\mathrm{Fe}(\mathrm{azp})_{2}\right]$ (Figure S1b), combined with $\mathrm{K}-\mathrm{OH}_{2} \cdots \mathrm{O}$ (phenolate)-Fe hydrogen-bonding pathways (Figure S1c).

The crystal packing is different in the two solvated forms. In the case of 1-ref, the 'dimer' moieties (vide supra) pack in sheets; see Figure S2a. In contrast, in 1, the chains are made up of alternating $\mathrm{K}(\mathrm{MeOH})\left(\mathrm{H}_{2} \mathrm{O}\right)_{2}{ }^{+}$and $\left[\mathrm{Fe}(\operatorname{azp})_{2}\right]^{-}$moieties and are paired together via hydrogen bonding occurring between the phenolate oxygen of one chain and the hydrogen of methanol that is coordinated to potassium in the other chain; Figure S2b. These H-bonding interactions are probably responsible for the spin state differences at the $\mathrm{Fe}^{\mathrm{III}}$ sites in the two solvates.

\subsection{Structural Analyses of Cationic Precursor Materials $\left[\mathrm{Fe}^{I I}\left\{(\mathrm{pz})_{3} \mathrm{CH}_{2}\right]\left[\mathrm{ClO}_{4}\right]_{2}(\mathrm{Compound}\right.$ 2) and $\left[\mathrm{Fe}^{\mathrm{II}}(\mathrm{TPPZ})_{2}\right]\left[\left(\mathrm{Fe}^{\mathrm{III}} \mathrm{Cl}_{3}\right)_{2} \mathrm{O}\right] \cdot 2 \mathrm{MeCN}$ (Compound 3)}

$\left[\mathrm{Fe}^{\mathrm{II}}\left\{(\mathrm{pz})_{3} \mathrm{CH}\right\}_{2}\right]\left[\mathrm{ClO}_{4}\right]_{2}(2)$ was previously reported and the magnetic properties of the compound in both solid and solution states have been reported $[27,28]$. However, the crystal structure of the compound has not been explored. Herein, we report the single crystal structure of 2 for the first time. Crystallographic data and selected Fe-L bond lengths of $\mathbf{2}$ are shown in Table S1 and Table S2. Compound 2 crystallizes in the monoclinic space group $P 2_{1} / n$ with only a half of the cationic $\mathrm{Fe}^{\mathrm{II}}$ complex, $\left[\mathrm{Fe}^{\mathrm{II}}\left\{(\mathrm{pz})_{3} \mathrm{CH}\right\}_{2}\right]^{2+}$ and an ionic molecule of $\mathrm{ClO}_{4}{ }^{-}$in the asymmetric unit (Figure ??a). 
At $123 \mathrm{~K}$, the Fe-N bond lengths of ca. $1.97 \AA$ and the octahedral parameters $[34,35]$ values of $\Sigma=29^{\circ}$ and $\Theta=35^{\circ}$ are indicative of $\mathrm{LS} \mathrm{Fe}{ }^{\mathrm{II}}$ [3]. It is noted that the asymmetric units of previous analogues $\left[\mathrm{Fe}^{\mathrm{II}}\left\{(\mathrm{pz})_{3} \mathrm{CH}\right\}_{2}\right] \mathrm{Y}_{\mathrm{n}}$ where $\mathrm{Y}=\left[\mathrm{Fe}(\mathrm{NCS})_{5}(\mathrm{py})\right][36](\mathrm{n}=1), \mathrm{NO}_{3}[28]$ and $\mathrm{BF}_{4}[29](\mathrm{n}=2)$ are all similarly composed of a half molecule of $\left[\mathrm{Fe}^{\mathrm{II}}\left\{(\mathrm{pz})_{3} \mathrm{CH}\right\}_{2}\right]^{2+}$. Compound 2 and $\left[\mathrm{Fe}^{\mathrm{II}}\left\{(\mathrm{pz})_{3} \mathrm{CH}\right\}_{2}\right]\left(\mathrm{BF}_{4}\right)_{2}$ [29] are isostructural. A sheet along the ac plane and a pseudo-3D network mainly forms via $\mathrm{C}-\mathrm{H} \cdots \mathrm{O}$ interactions between the $\left[\mathrm{Fe}^{\mathrm{II}}\left\{(\mathrm{pz})_{3} \mathrm{CH}\right\}_{2}\right]^{2+}$ moieties and perchlorate anions in 2 (Figure S3 and Table S3).

Another cationic precursor for double salt compound formation is $\left[\mathrm{Fe}^{\mathrm{II}}(\mathrm{TPPZ})_{2}\right]\left[\left(\mathrm{Fe}^{\mathrm{III}} \mathrm{Cl}_{3}\right)_{2} \mathrm{O}\right] \cdot 2 \mathrm{MeCN}$ (3). The crystal structure of 3 has been examined at 100 and $300 \mathrm{~K}$ and they both crystallise in the triclinic space group $\mathrm{P} \overline{1}$ (Table S1). The unit cell parameters of 3 at $300 \mathrm{~K}$ are slightly larger than those at $100 \mathrm{~K}$. Consequently, the cell volume at higher temperature is bigger than that at low temperature by about $2 \%$. The asymmetric unit of 3 in Figure ??b contains the bis-mer-tridentate $\mathrm{Fe}^{\mathrm{II}}$ cation, an anionic molecule of $\left[\mathrm{Fe}^{\mathrm{III}} \mathrm{Cl}_{3}-\mathrm{O}-\mathrm{Fe}^{\mathrm{III}} \mathrm{Cl}_{3}\right]^{2-}$, a well-known antiferromagnetically coupled $\mu$-oxoirom(III) dimer [37] and two molecules of MeCN solvate. In 2005, Hanks et al. investigated all possible conformations of TPPZ ligands and defined conventional names for each conformation relating to positions of the four pyridyl nitrogen atoms [38]. Applying the same rule to compound 3, we found that the conformation of TPPZ ligands in the compound at 100 and $300 \mathrm{~K}$ are the same. However, one of the TPPZ ligand in 3 shows $1 \mathrm{NXNN}$ conformation while the other one shows $2 \mathrm{XXNN}$ conformation.

Selected Fe-N bond lengths given in Table S2 for the $\left[\mathrm{Fe}^{\mathrm{II}}(\mathrm{TPPZ})_{2}\right]^{2+}$ cation are similar to the Fe-N distances that were found in 2 which suggest the LS state for $\mathrm{Fe}^{\mathrm{II}}$ exists at both 100 and $300 \mathrm{~K}$. However, the high values of the $\Sigma=80^{\circ}$ and $81^{\circ}$ and $\Theta=240^{\circ}$ and $252^{\circ}$ at 100 and $300 \mathrm{~K}$, respectively are of a high degree of distortion around the $\mathrm{Fe}^{\mathrm{II}}$ centres which is unusual for the LS form. This phenomenon, where the Fe-N bond lengths are short and suggest the LS form while the octahedral distortion parameters are large and suggestive of $\mathrm{HS}$, at the metal centre, is also found in other $\left[\mathrm{Fe}^{\mathrm{II}}(\mathrm{TPPZ})_{2}\right](\mathrm{Y})_{2}$ compounds such as when $\mathrm{Y}=\mathrm{PF}_{6}[39]$ and $\mathrm{ClO}_{4}$ [30]. This phenomenon then might be a unique characteristic of $\left[\mathrm{Fe}^{\mathrm{II}}(\mathrm{TPPZ})_{2}\right](\mathrm{Y})_{2}$ compounds. It is known that all four pyridyl rings of TPPZ cannot be coplanar with the pyrazine because of steric crowding $[31,38]$. This might be a reason for the high degree of distortion around the metal centres of $\left[\mathrm{Fe}^{\mathrm{II}}(\mathrm{TPPZ})_{2}\right](\mathrm{Y})_{2}$ compounds even though they are in the LS states.

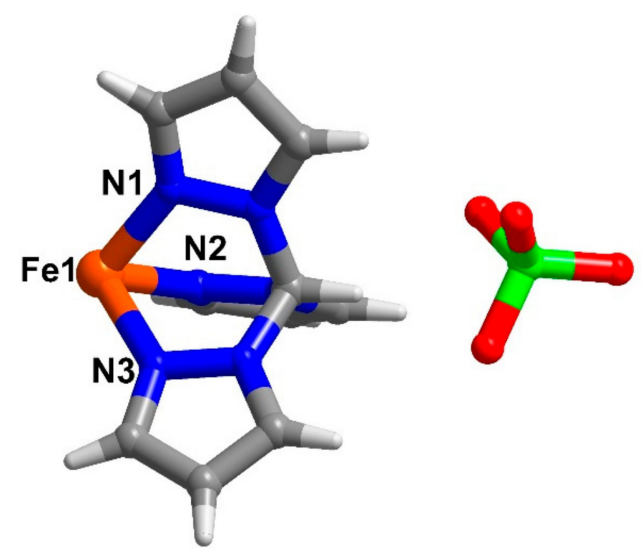

(a)

Figure 3. Cont. 


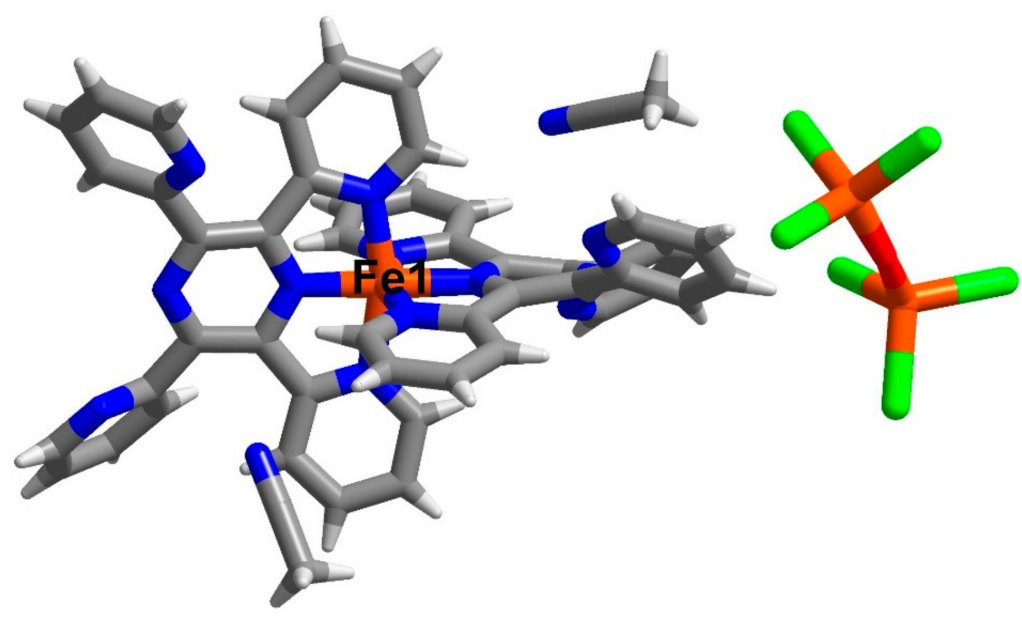

(b)

Figure 3. The asymmetric unit of compound (a) 2 and (b) 3 at 123 and $100 \mathrm{~K}$, respectively. Colour code (element): brown (iron), red (oxygen), blue (nitrogen), grey (carbon) and white (hydrogen), green (chlorine).

Regarding to the crystal packing in 3 , the cationic $\left[\mathrm{Fe}^{\mathrm{II}}(\mathrm{TPPZ})_{2}\right]^{2+}$ molecules are connected through the adjacent anion $\left[\mathrm{Fe}^{\mathrm{III}} \mathrm{Cl}_{3}-\mathrm{O}-\mathrm{Fe} \mathrm{III}^{\mathrm{II}} \mathrm{Cl}_{3}\right]^{2-}$ via $\mathrm{C}-\mathrm{H} \cdots \mathrm{Cl}$ interactions yielding a chain along the $c$ axis (Figure S4a). The neighbouring 1D chains are linked further into a 2D sheet again though $\mathrm{C}-\mathrm{H} \cdots \mathrm{Cl}$ interactions from the anionic molecules (Figure S4b). Aromatic rings on the TPPZ ligands also play a role in the crystal packing by forming three types of the parallel fourfold aryl embrace (P4AE) [40] interactions (Figure S4c) producing a pseudo-2D sheet of the $\mathrm{Fe}^{\mathrm{II}}$ cations in the $a b$ plane. Selected intermolecular interactions in 3, at 100 and $300 \mathrm{~K}$, are shown in Table S4. It is expected that all such interactions in the compound at $100 \mathrm{~K}$ will be shorter than those at higher temperature.

\subsection{Structural Analysis for Double Spin Crossover Materials (Compound 4-6)}

Single crystal structures for compound 4-6 were obtained at multiple temperatures i.e., 100 and $300 \mathrm{~K}$. The crystallographic data are gathered together in Table 1 . Compound $\left[\mathrm{Fe}^{\mathrm{II}}\left\{(\mathrm{pz})_{3} \mathrm{CH}\right\}_{2}\right]\left[\mathrm{Fe}^{\mathrm{III}}(\mathrm{azp})_{2}\right]_{2} \cdot 2 \mathrm{H}_{2} \mathrm{O}(4)$, crystallizes in the triclinic space group $P \overline{1}$, while $\left[\mathrm{Fe}^{\mathrm{II}}(\mathrm{TPPZ})_{2}\right]\left[\mathrm{Fe}^{\mathrm{III}}(\mathrm{azp})_{2}\right]_{2} \cdot \mathrm{H}_{2} \mathrm{O}(\mathbf{5})$ and $\left[\mathrm{Fe}^{\mathrm{II}}(\mathrm{TPPZ})_{2}\right]\left[\mathrm{Fe}^{\mathrm{III}}(\mathrm{azp})_{2}\right]_{2} \cdot \mathrm{H}_{2} \mathrm{O} \cdot 3 \mathrm{MeCN}(\mathbf{6})$ similarly crystallize in the monoclinic space group, $\mathrm{P}_{1} / n$. The crystal systems for each sample are the same at temperatures 100 and $300 \mathrm{~K}$. The asymmetric units of 4 (Figure $4 \mathrm{a}$ ) contain a half molecule of the cationic $\left[\mathrm{Fe}^{\mathrm{II}}\left\{(\mathrm{pz})_{3} \mathrm{CH}\right\}_{2}\right]^{2+}$ moiety, an anionic molecule of $\left[\mathrm{Fe}^{\mathrm{III}}(\mathrm{azp})_{2}\right]^{-}$and a molecule of water of solvation. Only a half molecule of $\left[\mathrm{Fe}^{\mathrm{II}}\left\{(\mathrm{pz})_{3} \mathrm{CH}\right\}_{2}\right]^{2+}$ in the asymmetric unit of 4 resemble what has been found in $\mathbf{2}$ and in other previous reports $[28,29,36]$. On the other hand, in compounds $\mathbf{5}$ and $\mathbf{6}$, the asymmetric units are similarly comprised of a cationic molecule of $\left[\mathrm{Fe}^{\mathrm{II}}(\mathrm{TPPZ})_{2}\right]^{2+}$, two anionic molecules of $\left[\mathrm{Fe}^{\mathrm{III}}(\mathrm{azp})_{2}\right]^{-}$and a molecule of water solvate (Figure $\left.4 \mathrm{~b}, \mathrm{c}\right)$. However, there are three molecules of $\mathrm{MeCN}$ solvates in the crystal lattice of compound 6. Warming up from 100 to $300 \mathrm{~K}$, the unit cell volumes of compound 4-6 are similarly larger by about $2 \%$ due to the thermal effect.

The anionic $\left[\mathrm{Fe}^{\mathrm{III}}(\mathrm{azp})_{2}\right]^{-}$centres in compound 4-6 coordinate to $\mathrm{N}_{2} \mathrm{O}_{4}$ donors from two azadiphenolato $\left(\mathrm{azp}^{2-}\right)$ ligands chelating in a meridional fashion. Fe-L bond lengths for the compounds are presented in Table 2. At $100 \mathrm{~K}, \mathrm{Fe} 1-\mathrm{O}$ and Fe1-N distances for 4 are 1.916-2.003 $̊$ and 2.099-2.190 , respectively. The octahedral distortion parameters $[34,35] \Sigma=100^{\circ}$ and $\Theta=293^{\circ}$ of the compounds are large in magnitude. Similar Fe1-L bond lengths and distortion parameters are also observed in compounds 5 and 6 collected at $100 \mathrm{~K}\left(\mathrm{Fe} 1-\mathrm{O}=1.949-1.996 \AA\right.$ and $\mathrm{Fe} 1-\mathrm{N}=2.164-2.190 \AA, \Sigma=103-106^{\circ}$ and $\left.\Theta=314-332^{\circ}\right)$. These data indicate that the $\mathrm{Fe} 1$ centres, $\left[\mathrm{Fe}^{\mathrm{III}}(\operatorname{azp})_{2}\right]^{-}$, are in the high spin (HS) states. At $300 \mathrm{~K}, \mathrm{Fe} 1-\mathrm{O}$ and Fe1-N distances for 4, 5 and $\mathbf{6}$ are similar to those observed at $100 \mathrm{~K}$ and are, again, typical for $\mathrm{HS} \mathrm{Fe}^{\mathrm{III}}$. 
The Fe2 centres in the other anionic $\left[\mathrm{Fe}^{\mathrm{III}}(\mathrm{azp})_{2}\right]^{-}$moiety, in $\mathbf{5}$ and $\mathbf{6}$, show Fe2-L bond lengths to be shorter than those distances found for Fe1-L particularly for Fe2-N i.e., $\mathrm{Fe} 2-\mathrm{O}=1.881-1.926 \AA$ and Fe2-N $=1.908-1.925 \AA$. These values are correlated to smaller values of the octahedral distortion parameters ( $\Sigma=36^{\circ}$ and $26^{\circ}$ and $\Theta=49^{\circ}$ and $44^{\circ}$ for 5 and 6 , respectively), and suggestive of low spin (LS) $\mathrm{Fe}^{\mathrm{III}}$ for the Fe2 centres. Upon warming up to $300 \mathrm{~K}$, the Fe2-O bond lengths are similar to those at $100 \mathrm{~K}$, while the Fe2-N distances are slightly longer by about 0.04 and $0.02 \AA$ for compound 5 and $\mathbf{6}$, respectively. Similarly, the octahedral distortion parameters of 5 and 6 increase by a tiny amount, about $\Delta \Sigma=1^{\circ}$, and $0^{\circ}$, and $\Delta \Theta=22^{\circ}$ and $8^{\circ}$ for 5 and $\mathbf{6}$, respectively. These changes in bond lengths and the distortion parameters of $\mathbf{5}$ and $\mathbf{6}$ are smaller than what would be expected for complete spin transitions from LS to HS forms [1]. This suggests that mostly the LS phase exists in the anionic $\left[\mathrm{Fe}^{\mathrm{III}}(\mathrm{azp})_{2}\right]^{-}$components in 5 and $\mathbf{6}$, at $300 \mathrm{~K}$.

For the cationic component in compound 4-6, the Fe-N bond lengths in Table 2 range between 1.88-1.98 $\AA$ and are similar to those reported, above, for the cationic precursors compound 2 and 3 , and all suggest the presence of $\mathrm{LS} \mathrm{Fe}{ }^{\mathrm{II}}$ for $4-6$ at both $100 \mathrm{~K}$ and $300 \mathrm{~K}$. Accordingly, the low values of the octahedral distortion parameters of $4\left(\Sigma=25^{\circ}\right.$ and $27^{\circ}$ and $\Theta=31^{\circ}$ and $32^{\circ}$ at 100 and $300 \mathrm{~K}$, respectively) are typical for LS-Fe ${ }^{\text {II. }}$. The ambiguity noted between bond distances and the octahedral distortion parameters in 3 , relating to the $\left[\mathrm{Fe}^{\mathrm{II}}(\mathrm{TPPZ})_{2}\right]$ moieties, are also present in $\mathbf{5}$ and $\mathbf{6}\left(\Sigma=79^{\circ}, \Theta=255^{\circ}\right.$ for $\mathbf{5}$ at both 100 and $300 \mathrm{~K}, \Sigma=78^{\circ}, \Theta=258^{\circ}$ and $260^{\circ}$ for 6 at 100 and $300 \mathrm{~K}$, respectively). In summary, the Fe-L bond lengths and the octahedral distortion parameters for the Fe centres of 4-6 at $100 \mathrm{~K}$ and $300 \mathrm{~K}$ are similar in cation and anion. It, therefore, suggests that there is no major spin transition taking place in 4-6 between 100 and $300 \mathrm{~K}$. For compound 4, there are a molecule of $1 \mathrm{HS} \mathrm{Fe}^{\mathrm{III}}$ and a half molecule of $1 \mathrm{LS} \mathrm{Fe}^{\mathrm{II}}$ in the asymmetric unit which means the ratio combination of the metals is $2 \mathrm{HS} \mathrm{Fe}^{\mathrm{III}}$ : $1 \mathrm{LS} \mathrm{Fe}^{\mathrm{II}}$. While in the case of $\mathbf{5}$ and $\mathbf{6}$, the spin states of the Fe centres are in the ratio 1HSFe ${ }^{\mathrm{III}}$ : 1LSFe ${ }^{\mathrm{III}}$ : $1 \mathrm{LS} \mathrm{Fe}^{\mathrm{II}}$.

It is noted that, the ambiguity noted between bond distances and the octahedral distortion parameters in $\mathbf{3}$, relating to the $\left[\mathrm{Fe}^{\mathrm{II}}(\mathrm{TPPZ})_{2}\right]$ moieties, are also present in $\mathbf{5}$ and $\mathbf{6}$. Although for both $\mathbf{5}$ and 6, the orientations of TPPZ ligands at 100 and $300 \mathrm{~K}$ remain the same. The conformations of the TPPZ ligands in $\mathbf{5}$ and $\mathbf{6}$ are different. In compound $\mathbf{5}$, the two ligands adopt different conformations i.e., $4 X X N N$ and $5 X X N N$ [38]. Whilst, it is only one conformation for the two ligands in $\mathbf{6}$ and it is the same as one of the TPPZ ligands in the precursor compound 3 which is in conformation 2XXNN [38].

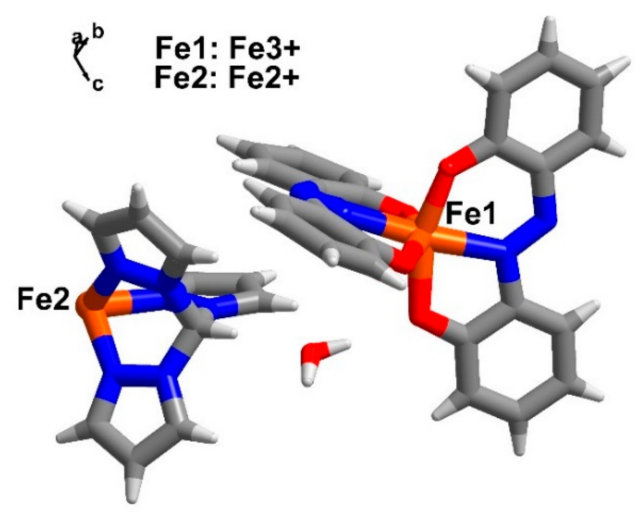

(a)

Figure 4. Cont. 


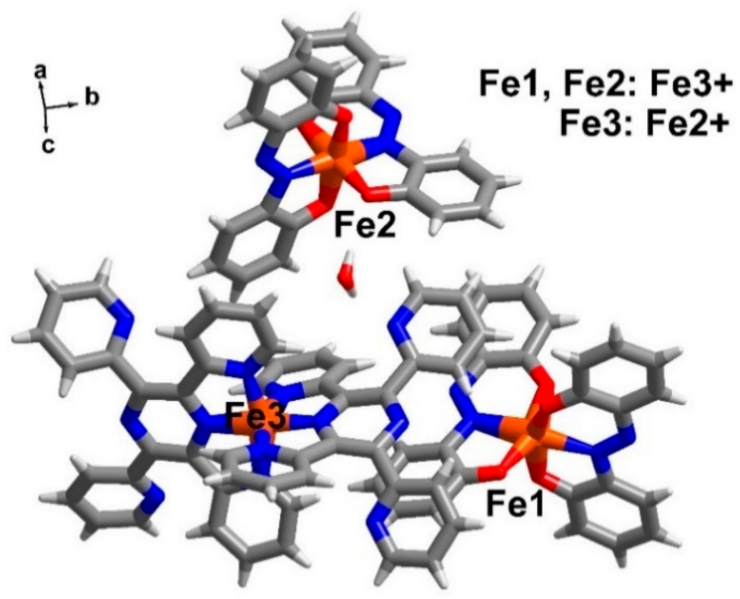

(b)

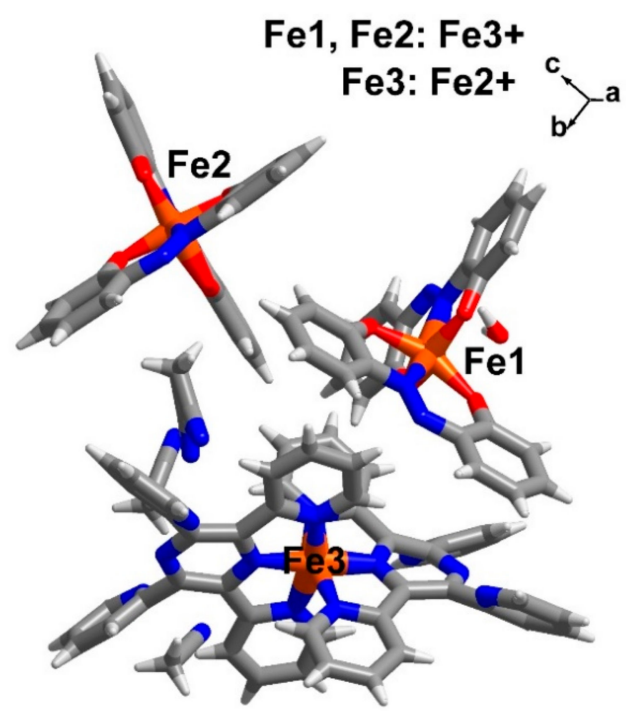

(c)

Figure 4. The asymmetric unit of compounds (a) 4, (b) 5 and (c) 6 in ball and stick model at $100 \mathrm{~K}$. Colour code (element): brown (iron), red (oxygen), blue (nitrogen), grey (carbon) and white (hydrogen). 
Table 1. Crystallographic data and structure refinement for 4-6.

\begin{tabular}{|c|c|c|c|c|c|c|}
\hline & \multicolumn{2}{|c|}{4} & \multicolumn{2}{|c|}{5} & \multicolumn{2}{|c|}{6} \\
\hline & $100 \mathrm{~K}$ & $300 \mathrm{~K}$ & $100 \mathrm{~K}$ & $300 \mathrm{~K}$ & $100 \mathrm{~K}$ & $300 \mathrm{~K}$ \\
\hline Formula & $\mathrm{C}_{68} \mathrm{H}_{56} \mathrm{Fe}_{3} \mathrm{~N}_{20} \mathrm{O}_{10}$ & $\mathrm{C}_{68} \mathrm{H}_{56} \mathrm{Fe}_{3} \mathrm{~N}_{20} \mathrm{O}_{10}$ & $\mathrm{C}_{96} \mathrm{H}_{66} \mathrm{Fe}_{3} \mathrm{~N}_{20} \mathrm{O}_{9}$ & $\mathrm{C}_{96} \mathrm{H}_{66} \mathrm{Fe}_{3} \mathrm{~N}_{20} \mathrm{O}_{9}$ & $\mathrm{C}_{102} \mathrm{H}_{75} \mathrm{Fe}_{3} \mathrm{~N}_{23} \mathrm{O}_{9}$ & $\mathrm{C}_{102} \mathrm{H}_{74} \mathrm{Fe}_{3} \mathrm{~N}_{23} \mathrm{O}_{8.50}$ \\
\hline Molecular weight $/ \mathrm{gmol}^{-1}$ & 1480.87 & 1480.87 & 1811.23 & 1811.23 & 1934.40 & 1925.39 \\
\hline Crystal system & Triclinic & Triclinic & Monoclinic & Monoclinic & Monoclinic & Monoclinic \\
\hline Space group & $\mathrm{P} \overline{1}$ & $\mathrm{P} \overline{1}$ & $\mathrm{P} 21 / \mathrm{n}$ & $\mathrm{P} 21 / \mathrm{n}$ & $\mathrm{P} 21 / \mathrm{n}$ & $\mathrm{P} 21 / \mathrm{n}$ \\
\hline $\mathrm{a} / \AA$ & $11.860(2)$ & $11.9211(2)$ & $12.650(3)$ & $12.760(3)$ & $12.075(2)$ & $12.212(2)$ \\
\hline $\mathrm{b} / \AA$ & $12.400(3)$ & $12.5340(2)$ & $18.010(4)$ & $18.130(4)$ & $25.936(5)$ & $26.134(5)$ \\
\hline$c / \AA$ & $13.420(3)$ & $13.5051(2)$ & $35.000(7)$ & $35.270(7)$ & $28.191(6)$ & $28.394(6)$ \\
\hline$\alpha / \mathrm{o}$ & $109.64(3)$ & $109.674(2)$ & 90 & 90 & 90 & 90 \\
\hline$\beta / \mathrm{o}$ & $114.74(3)$ & $114.771(2)$ & $99.97(3)$ & $99.86(3)$ & $94.67(3)$ & $94.57(3)$ \\
\hline$\gamma / \mathrm{o}$ & $93.63(3)$ & $93.838(2)$ & 90 & 90 & 90 & 90 \\
\hline Cell volume $/ \AA^{3}$ & $1639.4(7)$ & $1673.46(6)$ & $7854(3)$ & $8039(3)$ & $8799(3)$ & $9033(3)$ \\
\hline $\mathrm{Z}$ & 1 & 1 & 4 & 4 & 4 & 4 \\
\hline Absorption coefficient $/ \mathrm{mm}^{-1}$ & 0.732 & 5.775 & 0.626 & 0.612 & 0.565 & 0.550 \\
\hline Reflections collected & 25901 & 33332 & 157439 & 169560 & 107312 & 110214 \\
\hline Independent reflections, $R_{\text {int }}$ & $6379,0.0395$ & $6931,0.0880$ & $23792,0.0448$ & $24544,0.0497$ & $24937,0.0488$ & $25677,0.0536$ \\
\hline Max. and min. transmission & 0.985 and 0.978 & 1.00000 and 0.55733 & 0.994 and 0.978 & 0.978 and 0.994 & 0.989 and 0.973 & 0.989 and 0.974 \\
\hline Restraints/parameters & $2 / 446$ & $0 / 479$ & $0 / 1161$ & $2 / 1161$ & $0 / 1273$ & $0 / 1210$ \\
\hline Final $R$ indices $[I>2 \sigma(I)]: R_{1}, w R_{2}$ & $0.0532,0.1472$ & $0.0570,0.1469$ & $0.0422,0.1118$ & $0.0490,0.1408$ & $0.0580,0.1534$ & $0.0536,0.1562$ \\
\hline CCDC number & 1905262 & 1905258 & 1905264 & 1905266 & 1905263 & 1905265 \\
\hline
\end{tabular}


Table 2. Selected bond lengths and octahedral distortion parameters for 4-6.

\begin{tabular}{|c|c|c|c|c|c|c|c|c|c|}
\hline \multicolumn{6}{|c|}{4} & \multicolumn{2}{|c|}{5} & \multicolumn{2}{|c|}{6} \\
\hline & & $100 \mathrm{~K}$ & $300 \mathrm{~K}$ & & & $100 \mathrm{~K}$ & $300 \mathrm{~K}$ & $100 \mathrm{~K}$ & $300 \mathrm{~K}$ \\
\hline \multirow[t]{6}{*}{$\mathrm{Fe}(\mathrm{III})$} & Fe1-O1/Å & $1.948(2)$ & $1.948(3)$ & $\mathrm{Fe}(\mathrm{III})$ & $\mathrm{Fe} 1-\mathrm{O} 1 / \AA$ & $1.9699(12)$ & $1.9706(16)$ & $1.9772(19)$ & $1.971(2)$ \\
\hline & $\mathrm{Fe} 1-\mathrm{O} 2 / \AA$ & 1.9409 (13) & $1.950(3)$ & & $\mathrm{Fe} 1-\mathrm{O} 2 / \AA$ & $1.9494(12)$ & $1.9481(17)$ & $1.9558(19)$ & $1.947(2)$ \\
\hline & $\mathrm{Fe} 1-\mathrm{O} 3 / \AA$ & $2.003(2)$ & $2.006(3)$ & & $\mathrm{Fe} 1-\mathrm{O} 3 / \mathrm{A}$ & $1.9962(12)$ & $1.9936(16)$ & $1.9860(19)$ & $1.982(2)$ \\
\hline & $\mathrm{Fe} 1-\mathrm{O} 4 / \AA$ & $1.916(2)$ & $1.926(3)$ & & $\mathrm{Fe} 1-\mathrm{O} 4 / \AA$ & $1.9563(13)$ & $1.9521(18)$ & $1.9590(18)$ & $1.954(2)$ \\
\hline & Fe1-N1 & $2.152(4)$ & $\begin{array}{r}2.149(5) \\
229(15)\end{array}$ & & $\mathrm{Fe} 1-\mathrm{N} 1 / \AA$ & 2.1901 (13) & $2.1907(16)$ & $2.174(2)$ & $2.175(2)$ \\
\hline & Fe1-N3/Å & $2.1368(17)$ & $2.162(3)$ & & $\mathrm{Fe} 1-\mathrm{N} 3 / \AA$ & $2.1638(13)$ & $2.1648(16)$ & $2.188(2)$ & $2.183(2)$ \\
\hline \multirow[t]{14}{*}{$\mathrm{Fe}(\mathrm{II})$} & $\mathrm{Fe} 2-\mathrm{N} 5 / \AA$ & $1.9739(12)$ & $1.968(3)$ & $\mathrm{Fe}(\mathrm{III})$ & $\mathrm{Fe} 2-\mathrm{O} 5 / \AA$ & $1.9135(13)$ & $1.9156(18)$ & $1.910(2)$ & $1.915(2)$ \\
\hline & $\mathrm{Fe} 2-\mathrm{N} 5 \mathrm{i} / \AA$ & 1.9739 (12) & $1.968(3)$ & & $\mathrm{Fe} 2-\mathrm{O} 6 / \AA$ & $1.8813(13)$ & 1.8945 (17) & $1.892(2)$ & $1.886(2)$ \\
\hline & $\mathrm{Fe} 2-\mathrm{N} 6 / \AA$ & $1.9735(12)$ & $1.975(3)$ & & $\mathrm{Fe} 2-\mathrm{O} 7 / \AA$ & $1.9259(12)$ & $1.9253(17)$ & $1.8835(19)$ & $1.879(2)$ \\
\hline & $\mathrm{Fe} 2-\mathrm{N} 6 \mathrm{i} / \AA$ & $1.9736(12)$ & $1.975(3)$ & & $\mathrm{Fe} 2-\mathrm{O} 8 / \AA$ & 1.8868 (12) & 1.8959 (16) & $1.9016(19)$ & 1.9085 (19) \\
\hline & $\mathrm{Fe} 2-\mathrm{N} 7 / \AA$ & 1.9611 (16) & $1.963(3)$ & & $\mathrm{Fe} 2-\mathrm{N} 5 / \AA$ & $1.9253(15)$ & $1.963(2)$ & $1.908(2)$ & $1.932(2)$ \\
\hline & $\mathrm{Fe} 2-\mathrm{N} 7 \mathrm{i} / \AA$ & $1.9610(16)$ & $1.963(3)$ & & $\mathrm{Fe} 2-\mathrm{N} 7 / \AA$ & $1.9107(13)$ & $1.9516(18)$ & $1.911(2)$ & $1.934(2)$ \\
\hline & $\Sigma /{ }^{\circ}(\mathrm{Fe} 1, \mathrm{Fe} 2)$ & 100,25 & 103,27 & $\mathrm{Fe}(\mathrm{II})$ & $\mathrm{Fe} 3-\mathrm{N} 9 / \AA$ & $1.9802(13)$ & $1.9840(15)$ & $1.956(2)$ & $1.9555(18)$ \\
\hline & $\Theta /{ }^{\circ}(\mathrm{Fe} 1, \mathrm{Fe} 2)$ & 293,31 & 308,32 & & $\mathrm{Fe} 3-\mathrm{N} 10 / \AA$ & $1.8861(12)$ & $1.8846(14)$ & $1.885(2)$ & 1.8825 (19) \\
\hline & & & & & $\mathrm{Fe} 3-\mathrm{N} 11 / \AA$ & $1.9699(13)$ & $1.9721(16)$ & $1.971(2)$ & $1.9666(19)$ \\
\hline & & & & & $\mathrm{Fe} 3-\mathrm{N} 12 / \AA$ & $1.9600(13)$ & $1.9596(15)$ & $1.972(2)$ & $1.977(2)$ \\
\hline & & & & & $\mathrm{Fe} 3-\mathrm{N} 13 / \AA$ & $1.8838(12)$ & $1.8833(14)$ & $1.880(2)$ & $1.8804(19)$ \\
\hline & & & & & $\mathrm{Fe} 3-\mathrm{N} 14 / \AA$ & $1.9652(13)$ & $1.9657(15)$ & $1.977(2)$ & $1.9812(19)$ \\
\hline & & & & & $\Sigma /{ }^{\circ}(\mathrm{Fe} 1, \mathrm{Fe} 2, \mathrm{Fe} 3)$ & $103,36,79$ & $100,37,79$ & $106,26,78$ & $101,26,78$ \\
\hline & & & & & $\Theta /{ }^{\circ}(\mathrm{Fe} 1, \mathrm{Fe} 2, \mathrm{Fe} 3)$ & $314,49,255$ & $302,71,255$ & $332,44,258$ & $319,52,260$ \\
\hline
\end{tabular}


The crystal packing in 4 is made up mainly of anionic sheets of $\left[\mathrm{Fe}^{\mathrm{III}}(\mathrm{azp})_{2}\right]^{-}$and cationic $\left[\mathrm{Fe}^{\mathrm{II}}\left\{(\mathrm{pz})_{3} \mathrm{CH}\right\}_{2}\right]^{2+}$ molecules which occupy positions between the $\mathrm{Fe} \mathrm{e}^{\mathrm{III}}$ layers (Figure $5 \mathrm{a}$ ). In an anionic sheet in the $a b$ plane, $\left[\mathrm{Fe}^{\mathrm{III}}(\mathrm{azp})_{2}\right]^{-}$molecules interact through $\pi-\pi$ and $\mathrm{C}-\mathrm{H} \cdots \pi$ interactions yielding a crossing net of $\mathrm{Fe}^{\mathrm{III}}$ molecules (Figure 5b, Table S5). The packing in 4, at 100 and $300 \mathrm{~K}$, is similar although intermolecular interactions are shorter at low temperature than those at $300 \mathrm{~K}$. This agrees with a slightly bigger size of the unit cell at high temperature.

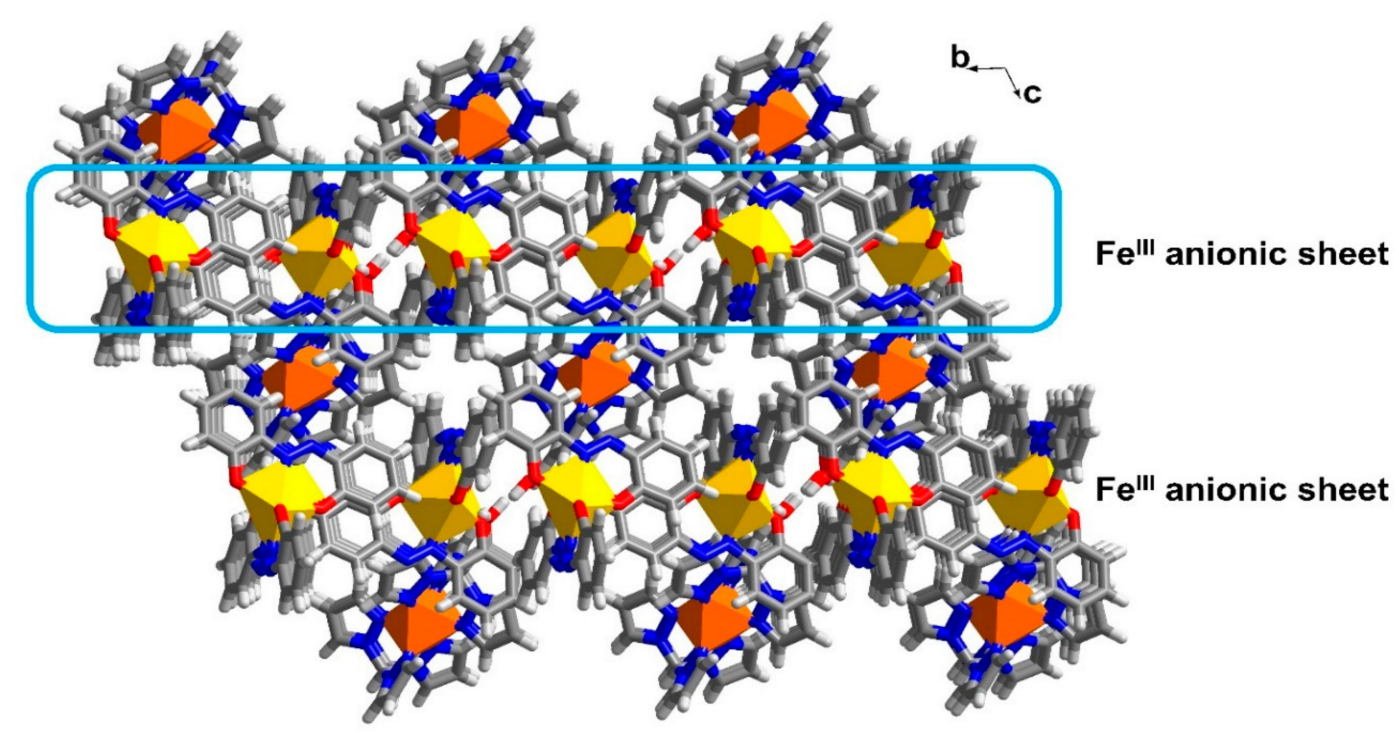

(a)

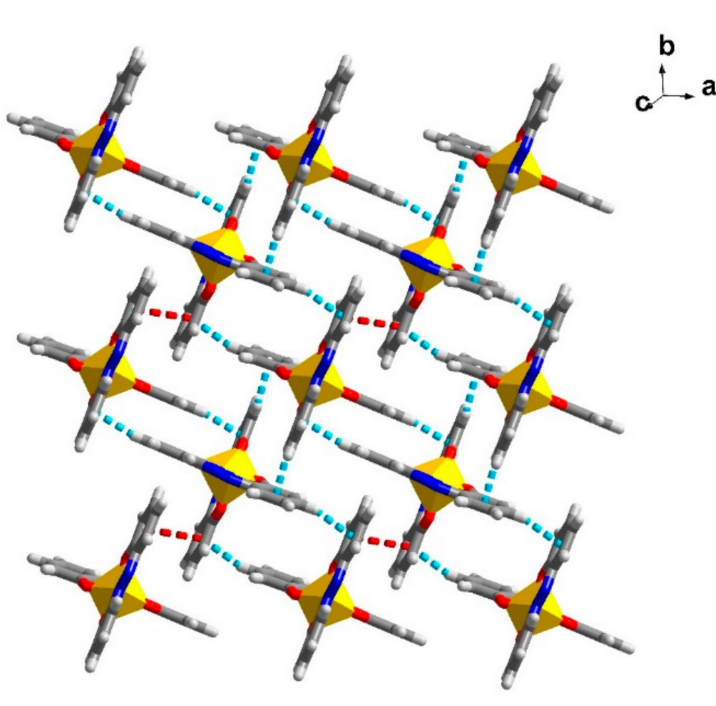

(b)

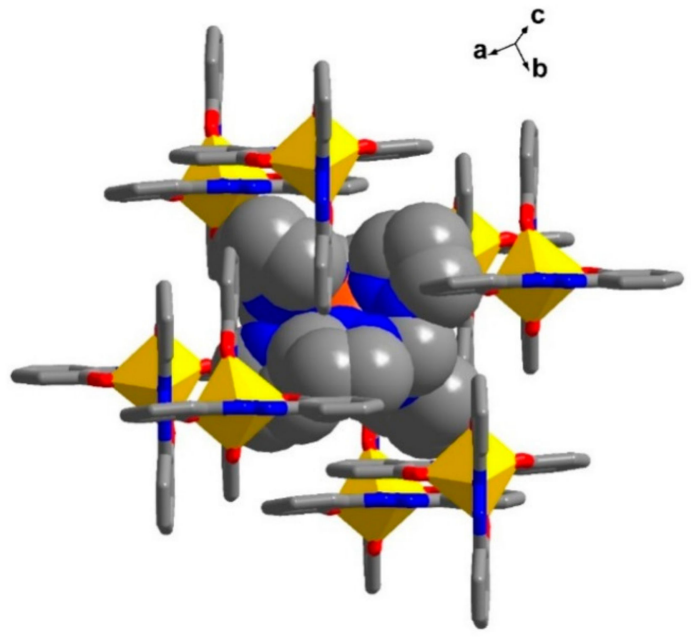

(c)

Figure 5. Crystal packing in 4 showing (a) the cationic $\mathrm{Fe}^{\mathrm{II}}$ molecules align in between the anionic $\mathrm{Fe}^{\mathrm{III}}$ sheet, (b) $\pi-\pi$ (red broken lines) and $\mathrm{C}-\mathrm{H} \cdots \pi$ (blue broken lines) interactions connecting $\left[\mathrm{Fe}^{\mathrm{III}}(\mathrm{azp})_{2}\right]^{-}$ moieties into a crossing net and (c) space filling model of a $\left[\mathrm{Fe}^{\mathrm{II}}\left\{(\mathrm{pz})_{3} \mathrm{CH}\right\}_{2}\right]^{2+}$ molecule in a pocket of $\left[\mathrm{Fe}^{\mathrm{III}}(\mathrm{azp})_{2}\right]^{-}$moieties. Yellow and orange polyhedral represent a coordination sphere of $\mathrm{Fe}^{\mathrm{III}}$ and $\mathrm{Fe}^{\mathrm{II}}$, respectively. 
In Figure $5 \mathrm{c}$, we see that the cationic $\left[\mathrm{Fe}^{\mathrm{I}}\left\{(\mathrm{pz})_{3} \mathrm{CH}\right\}_{2}\right]^{2+}$ molecules are located in a pocket formed by eight molecules of anionic $\left[\mathrm{Fe}^{\mathrm{III}}(\mathrm{azp})_{2}\right]^{-}$. The $\mathrm{Fe}^{\mathrm{II}}$ and $\mathrm{Fe}^{\mathrm{III}}$ molecules are connected through $\pi-\pi$ and $\mathrm{C}-\mathrm{H} \cdot \cdots \mathrm{O} / \mathrm{N}$ interactions (Figure S5). It is noted that there is no direct connection between $\mathrm{Fe}^{\mathrm{II}}$ molecules such that $\mathrm{Fe}^{\mathrm{II}}-\mathrm{Fe}^{\mathrm{II}}$ distances at $100 \mathrm{~K}$ are $11.86 \AA$ and $12.40 \AA$ along the $a$ and $b$ axes, respectively. The isolation between adjacent $\left[\mathrm{Fe}^{\mathrm{II}}\left\{(\mathrm{pz})_{3} \mathrm{CH}\right\}_{2}\right]^{2+}$ molecules that prefer to interact with anions around the metal centre and have no intermolecular interaction with other $\mathrm{Fe}^{\mathrm{II}}$ cationic molecules is similar to what is found in the cationic precursor, compound 2. In Figure S3c, the $\left[\mathrm{Fe}^{\mathrm{II}}\left\{(\mathrm{pz})_{3} \mathrm{CH}\right\}_{2}\right]^{2+}$ cations also occupy the pockets of $\mathrm{ClO}_{4}{ }^{-}$anions and do not form intermolecular interactions with other neighbouring $\mathrm{Fe}^{\mathrm{II}}$ molecules. This might be the reason for the similar LS states at the $\mathrm{Fe}^{\mathrm{II}}$ centres in both $\mathbf{2}$ and $\mathbf{4}$.

For the $\mathrm{Fe}^{\mathrm{III}}$ anions, the packing of $\left[\mathrm{Fe}^{\mathrm{III}}(\operatorname{azp})_{2}\right]^{-}$is varied depending on the counter cationic molecules present [9]. Therefore, it is not surprising that the packing of $\left[\mathrm{Fe}^{\mathrm{III}}(\mathrm{azp})_{2}\right]^{-}$molecules in the double salt product, 4 , and the anionic precursor, $\mathbf{1}$ are different. While the $\mathrm{K}(\mathrm{MeOH})\left(\mathrm{H}_{2} \mathrm{O}\right)_{2}{ }^{+}$ moiety in $\mathbf{1}$ forms a $1 D$-chain with the $\mathrm{Fe}^{\mathrm{III}}$ centre via $\eta_{4}$ interactions from $\mathrm{K}^{+}$to one of the aromatic ring, $\left[\mathrm{Fe}^{\mathrm{II}}\left\{(\mathrm{pz})_{3} \mathrm{CH}\right\}_{2}\right]^{2+}$ is too big and has no possible donor atoms to support similar type of packing. However, similar interactions such as the $\pi-\pi$ and $\mathrm{C}-\mathrm{H} \cdots \pi$ interactions that link $\left[\mathrm{Fe}^{\mathrm{III}}(\mathrm{azp})_{2}\right]^{-}$in compound 4 into a cationic sheet are similar to what was found in $\left[\mathrm{Fe}^{\mathrm{III}}(\mathrm{azp})_{2}\right]^{-}$complexes containing bulky organic cations such as tetrabutylammonium [9]. However, in that case the interactions connect $\left[\mathrm{Fe}^{\mathrm{III}}(\mathrm{azp})_{2}\right]^{-}$molecules into a 1D-chain, along the $c$ axis.

The separation between cationic and anionic sheets in the crystal packing is also found in compound 5 (Figure 6a). However, the difference from 4 is that, in 5, there are two types of $\left[\mathrm{Fe}^{\mathrm{III}}(\mathrm{azp})_{2}\right]^{-}$; with $\mathrm{Fe} 1$ and $\mathrm{Fe} 2$ displaying different spin states (Fe1 is HS and Fe2 is LS) and they form intermolecular interactions in different fashions. In Figure $6 b$, the anionic sheet of LS-Fe2 molecules is formed via $\mathrm{C}-\mathrm{H} \cdots \mathrm{N}$ and $\mathrm{O}-\mathrm{H}\left(\mathrm{H}_{2} \mathrm{O}\right) \cdots \mathrm{O}$ interactions in an $a b$ plane, while HS-Fe1 moieties show two types of $\pi \cdots \pi$ interactions with $\left[\mathrm{Fe}^{\mathrm{II}}(\mathrm{TPPZ})_{2}\right]^{2+}$ molecules yielding a pseudo-1D chain of HS-Fe ${ }^{\mathrm{III}}$-LS-Fe ${ }^{\mathrm{II}}-\mathrm{HS}-\mathrm{Fe}^{\mathrm{III}}-\mathrm{LS}-\mathrm{Fe}^{\mathrm{II}}$ along the $b$ axis (Figure $6 \mathrm{c}$ ). A close look of the $\pi \cdots \pi$ interactions is shown in Figure S6. Each type of interaction is composed of one $\pi \cdots \pi$ interaction and one $\mathrm{C}-\mathrm{H} \cdots \pi$ interaction from pyridine rings of TPPZ to aromatic rings of azp ligands. Each mixed oxidation chain also forms other two tyes of $\pi \cdots \pi$ interactions (Type $C$ and D, Figure S6c,d) with adjacent chains giving rise to a pseudo-2D sheet of HS-Fe ${ }^{\mathrm{III}}$-LS-Fe ${ }^{\mathrm{II}}$. In the case of $\pi \cdots \pi$ interactions of type $\mathrm{C}$, they are formed by the interaction between two pyridine rings of two $\left[\mathrm{Fe}^{\mathrm{II}}(\mathrm{TPPZ})_{2}\right]^{2+}$ molecules. A $\pi \cdots \pi$ interaction of type D involves a pyridine ring of TPPZ and an aromatic ring of the coordinated azp ligand. Finally, in 5, the anionic sheets of LS-Fe2 are held to the sheet of HS-Fe ${ }^{\mathrm{III}}-\mathrm{LS}-\mathrm{Fe}^{\mathrm{II}}$ (Figure S7a) via $\pi \cdots \pi$ interactions between two types of $\left[\mathrm{Fe}^{\mathrm{III}}(\mathrm{azp})_{2}\right]^{-} ; \mathrm{Fe} 1$ and $\mathrm{Fe} 2$ (Figure S7b). Selected intermolecular distances in $\mathbf{5}$ are shown in Table S6. 


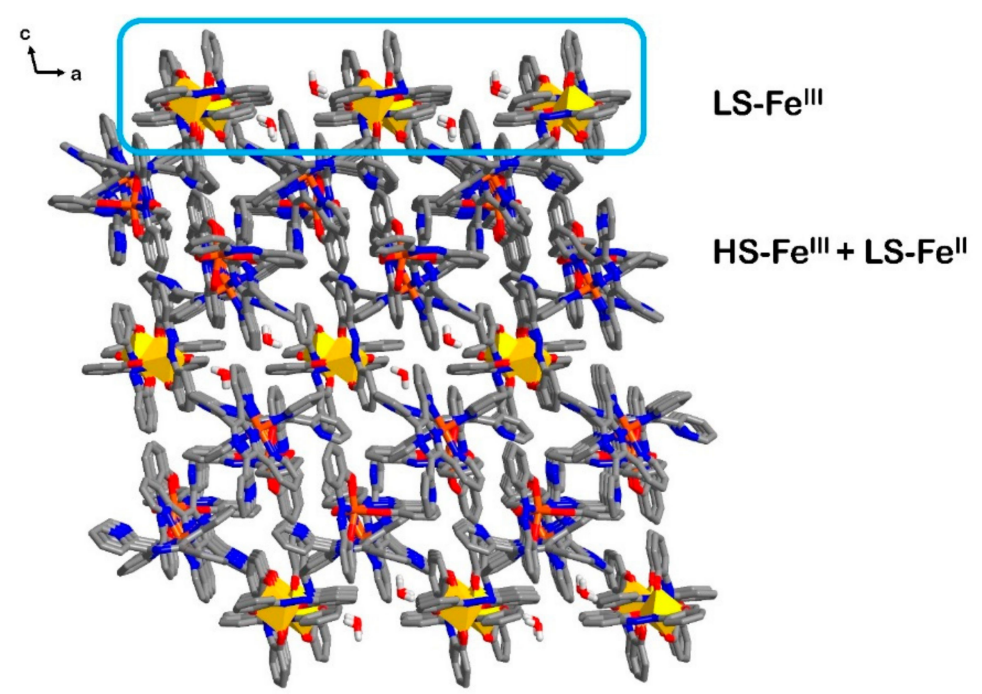

(a)

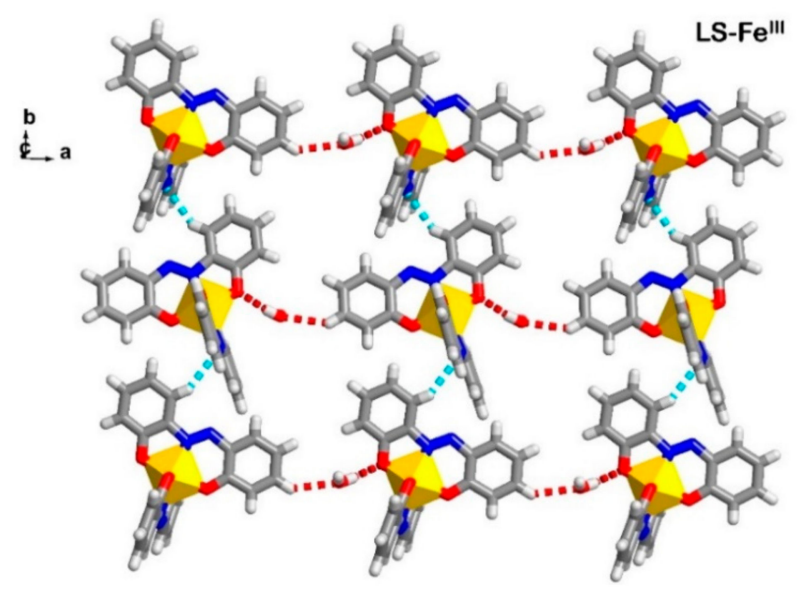

(b)

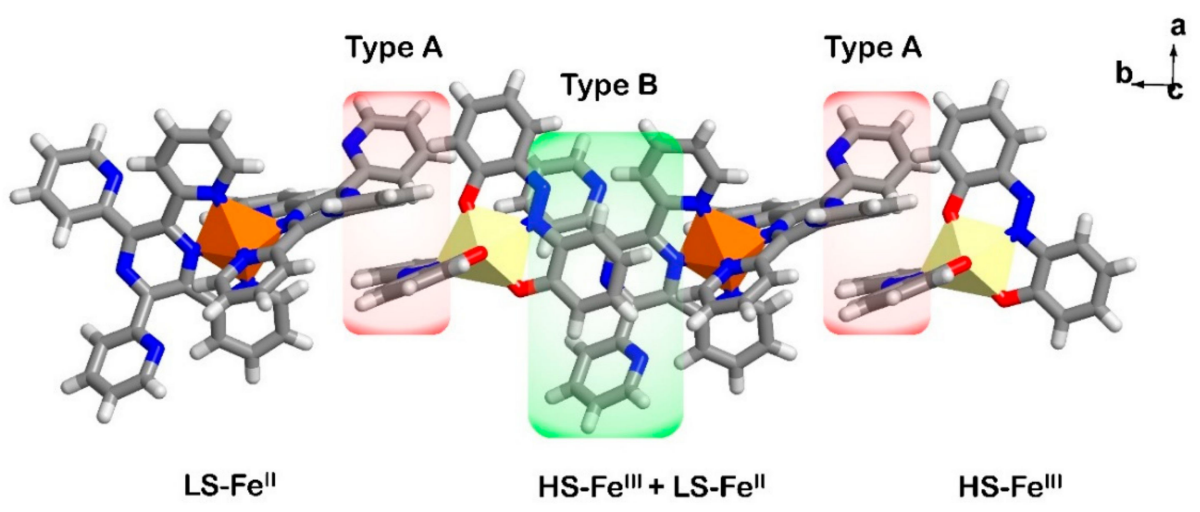

(c)

Figure 6. Crystal packing in 5 showing (a) the LS-Fe ${ }^{I I}$ and HS-Fe ${ }^{I I I}$ molecules aligned in between another sheet of anionic LS-Fe ${ }^{\mathrm{III}}$, (b) $\mathrm{O}-\mathrm{H} \cdots \mathrm{O}$ (red broken lines) and $\mathrm{C}-\mathrm{H} \cdots \mathrm{N}$ (blue broken lines) interactions connecting $\left[\mathrm{Fe}^{\mathrm{III}}(\mathrm{azp})_{2}\right]^{-}$moieties in the anionic sheet and (c) two types of $\pi \cdots \pi$ interactions linking LS-Fe $\mathrm{F}^{\mathrm{II}}$ and HS-Fe ${ }^{\mathrm{III}}$ molecules into a 1D chain along the $b$ axis. Yellow and light yellow polyhedral represent coordination sphere of a LS-Fe ${ }^{\mathrm{III}}$ and HS-Fe ${ }^{\mathrm{III}}$, respectively. While, the orange polyhedral represents the LS-Fe ${ }^{I I}$. 
It is noted that the crystal packing diagrams for $\mathbf{4}$ and $\mathbf{5}$ which show layered structures consisting of the $\left[\mathrm{Fe}^{\mathrm{III}}(\operatorname{azp})_{2}\right]^{-}$counter-anion and the $\left[\mathrm{Fe}^{\mathrm{II}} \mathrm{L}_{2}\right]^{2+}$ complex cation are similar to those previously reported for mixed-valent iron(II)/iron(III) compounds such as $\left[\mathrm{Fe}^{\mathrm{II}} \mathrm{L}_{\mathrm{X}}\right]\left[\mathrm{Fe}^{\mathrm{III}}\left(\text { dipic) }{ }_{2}\right]_{Y}\right.$ where dipic ${ }^{2-}=$ 2,6-pyridinedicarboxylate $[18,19,41]$ and the homochiral assembly in $\left[\mathrm{Fe}^{\mathrm{II}} \mathrm{H}_{3} \mathrm{~L}\right]\left[\mathrm{Fe}^{\mathrm{III}} \mathrm{L}\right] \mathrm{X}_{2}$ where $\mathrm{H}_{3} \mathrm{~L}=$

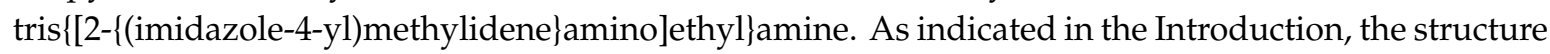
is made up from the homochiral stacking of 2D sheets. One layer contains only $\left[\mathrm{Fe}^{\mathrm{II}} \mathrm{H}_{3} \mathrm{~L}\right]^{2+}$ species, while the other layer contains only $\left[\mathrm{Fe}^{\mathrm{III}} \mathrm{L}\right]$ species [17].

As mentioned earlier, there are extra three molecules of $\mathrm{MeCN}$ in 6 in comparison to 5 . These solvate molecules give rise to a new crystal packing mode that does not show a clear separation between cationic and anionic sheets as described, above, for 4 and 5. In Figure 7a, a pseudo chain of Fe centres i.e., $\mathrm{LS}-\mathrm{Fe}^{\mathrm{III}}$, $\mathrm{LS}-\mathrm{Fe}^{\mathrm{II}}$ and HS-Fe ${ }^{\mathrm{III}}$ is shown along the $\mathrm{b}$ axis. In this chain, each type of $\left[\mathrm{Fe}^{\mathrm{III}}(\mathrm{azp})_{2}\right]^{-}$, LS and HS, form a dimer with the same type of molecules via C-H..O interactions. Different types of dimer are further connected in a chain through $\mathrm{C}-\mathrm{H} \cdots \pi$ interactions from $\left[\mathrm{Fe}^{\mathrm{II}}(\mathrm{TPPZ})_{2}\right]^{2+}$ molecules. These $\left[\mathrm{Fe}^{\mathrm{II}}(\mathrm{TPPZ})_{2}\right]^{2+}$ molecules concurrently form C-H $\cdots \pi$ interactions with other $\mathrm{Fe}^{\mathrm{II}}$ moieties along the a axis (Figure S8a) resulting in a chain of $\left[\mathrm{Fe}^{\mathrm{II}}(\mathrm{TPPZ})_{2}\right]^{2+}$ which further interact with adjacent $\mathrm{Fe}^{\mathrm{III}}$ molecules (Table S7). This produces a pseudo-2D sheet along the ab plane (Figure S8b). It is noted that each $\mathrm{Fe}^{\mathrm{III}}$ dimer does not have intermolecular interactions to other dimers. Although aromatic-aromatic rings from azp ${ }^{2-}$ ligand stacks are found, the inter-planar distances are too large to form $\pi-\pi$ interactions. Therefore, there are only intermolecular interactions relating to $\left[\mathrm{Fe}^{\mathrm{II}}(\mathrm{TPPZ})_{2}\right]^{2+}$ molecules that support a sheet of three distinct Fe centres on an ab plane. Acetonitrile solvent molecules play an important role in connecting these Fe sheets and producing a pseudo-3D network (Figure 7b and Figure S8c). It is obvious, therefore, that solvents in the crystal lattice provide subtle but important impacts on crystal packing in $\mathbf{5}$ and $\mathbf{6}$.

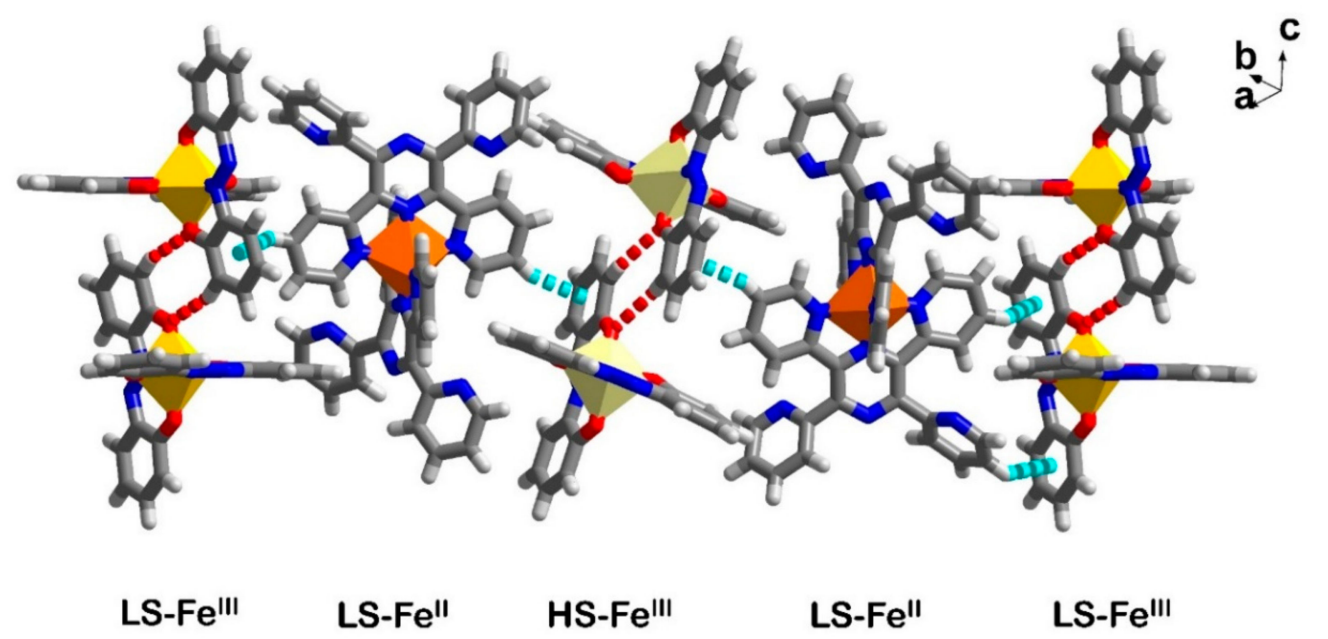

(a)

Figure 7. Cont. 


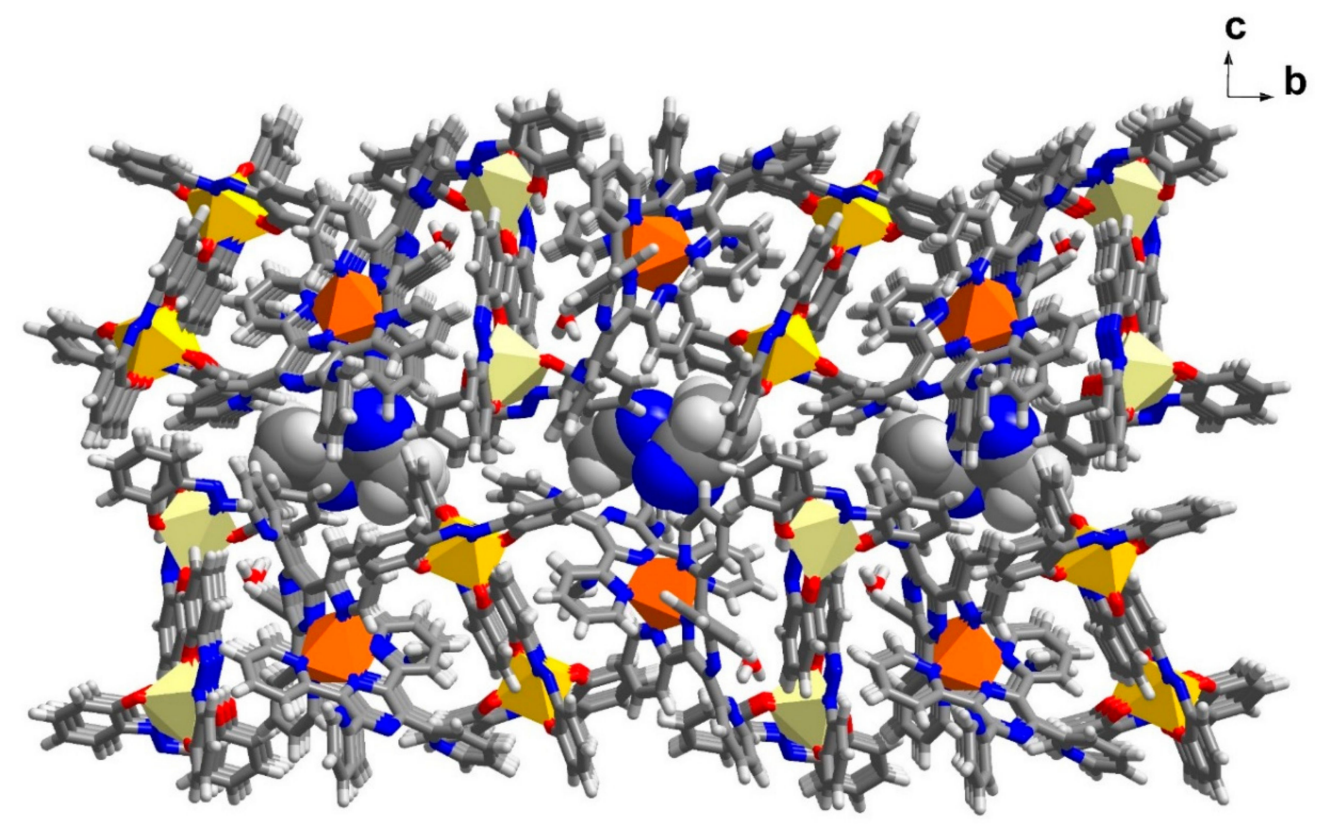

(b)

Figure 7. Illustration of crystal packing in 6 (a) a chain along the $a$ axis linking via O-H $\cdots \mathrm{O}$ (red broken lines) and C-H $\cdots \pi$ (blue broken lines) and (b) the pseudo-3D packing with a space filling model of $\mathrm{MeCN}$ solvate molecules in between two layers of Fe moieties.

\subsection{Magnetic Susceptibility Results}

The variable-temperature magnetic susceptibility data for compound $\left[\mathrm{Fe}^{\mathrm{II}}(\mathrm{TPPZ})_{2}\right]\left[\mathrm{Fe}^{\mathrm{III}}(\mathrm{azp})_{2}\right]_{2} \cdot \mathrm{H}_{2} \mathrm{O} \cdot 3 \mathrm{MeCN} 6$ were obtained over the $36-360 \mathrm{~K}$ temperature range without any protective coating applied to the crystalline sample of 6 . All the experiments were conducted under a DC field of $0.5 \mathrm{~T}$ and at a heating/cooling rate of $10 \mathrm{~K} \mathrm{~min}^{-1}$ in the settle mode. From Figure 8 , at $36 \mathrm{~K}$ the magnetic susceptibility is ca. $4.8 \mathrm{~cm}^{3} \mathrm{~mol}^{-1} \mathrm{~K}$ which is indicative of the spin state components being $1 \mathrm{HS} \mathrm{Fe}^{\mathrm{III}}$, $1 \mathrm{LS} \mathrm{Fe}{ }^{\mathrm{III}}$ and $1 \mathrm{LS}$ Fe ${ }^{\mathrm{II}}$ (expected $\chi_{\mathrm{M}} T$ is $4.375+0.375+0=4.75 \mathrm{~cm}^{3} \mathrm{~mol}^{-1}$ $\mathrm{K})$. This result agrees well with the single crystal structure data of 6 at $100 \mathrm{~K}$. Upon warming, the spin transitions begin to take place at around $220 \mathrm{~K}$ and reach the maximum of the $\chi_{\mathrm{M}} T$ value of $6.79 \mathrm{~cm}^{3}$ $\mathrm{mol}^{-1} \mathrm{~K}$ at $360 \mathrm{~K}$. The profile tends to keep increasing as the temperature increases and might reach fully spin crossover at higher temperature. At $360 \mathrm{~K}$, the $\chi_{\mathrm{M}} T$ value increase by about $2 \mathrm{~cm}^{3} \mathrm{~mol}^{-1} \mathrm{~K}$ indicating an incomplete spin transition emanating either from the $\mathrm{Fe}^{\mathrm{III}}$ or Fe $\mathrm{F}^{\mathrm{II}}$ centres. According to the single crystal structure of 6 at $300 \mathrm{~K}, \mathrm{Fe}-\mathrm{N}$ bond lengths at the $\mathrm{Fe} 2-\mathrm{Fe}{ }^{\mathrm{III}}$ site increase in average by about $0.02 \AA$ while the bond distances for the $\mathrm{Fe} 3-\mathrm{Fe}^{\mathrm{II}}$ site increase slightly by only $0.0004 \AA$. It suggests that the spin state of $\mathrm{Fe} 3-\mathrm{Fe}^{\mathrm{II}}$ remain the same from 100 to $300 \mathrm{~K}$. Consequently, the spin transition taking place in 6 should be from the $\mathrm{Fe} 2-\mathrm{Fe}^{\mathrm{III}}$ molecules. In conclusion, the $\mathrm{Fe}^{\mathrm{II}}$ centre remains $\mathrm{LS}$, one of the $\mathrm{Fe}^{\mathrm{III}}$ centre remains $\mathrm{HS}$ and one of the $\mathrm{Fe}^{\mathrm{III}}$ shows incomplete spin crossover up to $360 \mathrm{~K}$. Notably, TGA results confirm the existence of $\mathrm{MeCN}$ solvates in the crystal lattice up to around $390 \mathrm{~K}$ (Figure S12). The spin transition in $\mathbf{6}$ is then suggested to be an intrinsic property of the Fe centres and not due to solvent loss. 


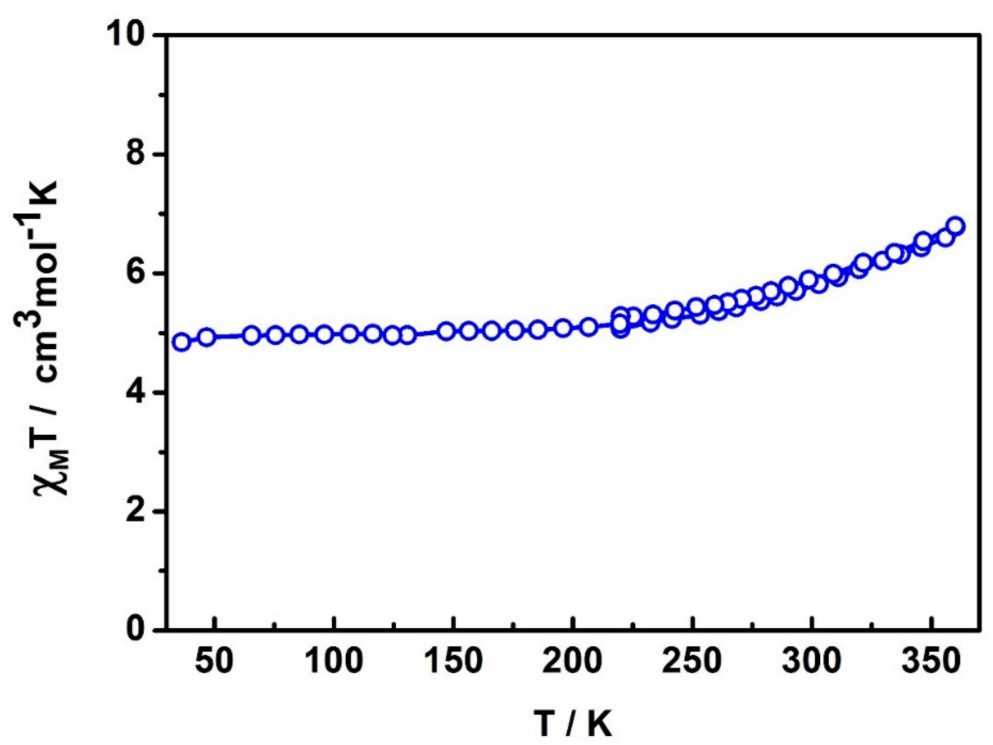

Figure 8. Variable-temperature magnetic susceptibility $\left(\chi_{M} \mathrm{~T}\right)$ measurements for compound 6 with heating and cooling shown in the range $220-360 \mathrm{~K}$.

\section{Materials and Methods}

\subsection{General}

All reagents and solvents were purchased from Sigma-Aldrich and used as received. Infrared spectra were measured using a Bruker Equinox 55 FTIR spectrometer fitted with a 71Judson MCT detector and Specac Golden Gate diamond ATR. Mass spectrometry analyses were performed using electrospray ionization mass spectra (ESI-MS) and were recorded with a Micromass (now Waters) ZMD with Waters alliance e2695 HPLC system for automatic sample injections. $\mathrm{MeOH}$ was the mobile phase which had a flow rate of $100 \mu \mathrm{L} \mathrm{min}{ }^{-1}$. TGA measurements were performed using a MettlerTGA/DSC 1 thermal analysis instrument at a heating rate of 2 or $5^{\circ} \mathrm{C} \mathrm{min}^{-1}$. Microanalyses were performed using the PerkinElmer ${ }^{\circledR} 2400$ Series II CHNS/O Elemental Analyzer. Variable-temperature magnetic susceptibility data were collected using either a Quantum Design MPMS 5 superconducting quantum interference device (SQUID) magnetometer or a MPMS XL-7 SQUID magnetometer, with a scan speed of $10 \mathrm{~K} \mathrm{~min}^{-1}$ followed by a one-minute wait after each temperature change. In cases in which steps were less than $10 \mathrm{~K}$ the target temperature was reached in less than $1 \mathrm{~min}$; hence it takes longer to stabilise at the target temperature. The sample was quenched from room temperature to $220 \mathrm{~K}$. The measurement started at $220 \mathrm{~K}$ and heated up to $360 \mathrm{~K}$. In the following cycle, the sample was cooled down to $36 \mathrm{~K}$. X-ray powder diffraction patterns were recorded with a Bruker D8 Advance powder diffractometer operating at $\mathrm{Cu} \mathrm{K} \alpha$ wavelength $(1.5418 \AA)$, with samples mounted on a zero-background silicon single crystal stage. Scans were performed at room temperature in the $2 \theta$ range $5-55^{\circ}$.

X-ray crystallographic measurements on $\mathbf{1}$ and $\mathbf{2}$ were collected at $123 \mathrm{~K}$ using a XtaLAB Synergy, Dualflex, HyPix diffractometer with $\mathrm{Cu}-K \alpha$ radiation $(\lambda=1.54184 \AA$ ). Single crystals were mounted on a glass fibre using oil. The data collection and integration were performed within CrysAlisPro software programs and corrected for absorption using CrysAlisPro 1.171.39.46 (Rigaku Oxford Diffraction, 2018).

X-ray crystallographic measurements on 3-6 were collected at the Australian Synchrotron operating at approximately $16 \mathrm{keV}(\lambda=0.71073 \AA)$. The collection temperature was maintained at specified temperatures using an open-flow $\mathrm{N}_{2}$ cryostream. Data were collected using Blue Ice software [42]. Initial data processing was carried out using the XDS package [43]. CCDC numbers are 1905257-1905266. These data are provided free of charge by The Cambridge Crystallographic Data Centre. 


\subsection{Synthesis of $\mathrm{K}\left[\mathrm{Fe}^{I I I}(a z p)_{2}\right] \cdot\left(\mathrm{H}_{2} \mathrm{O}\right)_{3} \cdot \mathrm{MeOH}, 1$}

The method followed that of Takahashi et al. [9] although that group obtained crystals with a different solvate composition and different crystallographic packing to that obtained here.

$2,2^{\prime}$-dihydroxoazobenzene $(0.43 \mathrm{~g}, 2 \mathrm{mmol})$ was suspended in ethanol $(10 \mathrm{~mL})$ to which potassium hydroxide $(0.24 \mathrm{~g}, 4.4 \mathrm{mmol})$ dissolved in ethanol $(8 \mathrm{~mL})$ was added, resulting in a black/brown solution. This solution was added, dropwise, to a solution of $\mathrm{FeCl}_{3}(162 \mathrm{mg}, 1 \mathrm{mmol})$ in ethanol $(5 \mathrm{~mL})$. This black/brown solution was left stirring overnight then filtered. After evaporation of the solvent from the filtrate a black, shiny powder was formed. This powder was recrystallised from a solution of methanol $(7 \mathrm{~mL})$ and diethylether $(7 \mathrm{~mL})$ to yield black crystals in $75 \%$ yield $(470 \mathrm{mg}) . \tilde{v}_{\max } / \mathrm{cm}^{-1} 2922\left(v_{\mathrm{Ar}-\mathrm{H}}\right), 1648\left(v_{\mathrm{C}=\mathrm{N}}\right), 1585\left(v_{\mathrm{C}=\mathrm{C}}\right), 1317\left(v_{\mathrm{C}-\mathrm{N}}\right), 1284\left(v_{\mathrm{C}-\mathrm{O}}\right)$. ESI-MS: $\mathrm{m} / z=$ $480\left[\mathrm{Fe}(\operatorname{azp})_{2}\right]^{-}$. Crystallography (vide infra) showed the crystals to be $\mathrm{K}\left[\mathrm{Fe}^{\mathrm{III}}(\operatorname{azp})_{2}\right] \cdot\left(\mathrm{H}_{2} \mathrm{O}\right)_{3} \cdot \mathrm{MeOH}$. Microanalysis on a bulk sample suggested the loss of methanol and water of solvation; calc. for $\mathrm{K}\left[\mathrm{Fe}(\mathrm{azp})_{2}\right] \cdot \mathrm{H}_{2} \mathrm{O}$ (found \%) $\mathrm{C}_{24} \mathrm{H}_{18} \mathrm{FeKN}_{4} \mathrm{O}_{5}$ : C, 53.64 (52.82); $\mathrm{H}, 3.38$ (3.45); N, 10.43 (10.31).

\subsection{Synthesis of $\left[\mathrm{Fe}^{\mathrm{II}}\left\{(\mathrm{pz})_{3} \mathrm{CH}\right\}_{2}\right]\left[\mathrm{ClO}_{4}\right]_{2}, 2$}

To prepare tris(pyrazolyl)methane, $\left((\mathrm{pz})_{3} \mathrm{CH}\right)$, pyrazole $(3.40 \mathrm{~g}, 50 \mathrm{mmol}), \mathrm{K}_{2} \mathrm{CO}_{3}(27.67 \mathrm{~g}$, $200 \mathrm{mmol})$ and tetrabutylammonium bromide $(0.80 \mathrm{~g}, 2.5 \mathrm{mmol})$ in $50 \mathrm{ml}$ of $\mathrm{CHCl}_{3}$ were refluxed for $72 \mathrm{hrs}$. A mixture of a brown solution and white precipitate was obtained, and this was filtered through paper under high pressure. The filtrate was then evaporated using a rotary evaporator giving an orange oil. Separately, the white precipitate was washed with diethyl ether $(3 \times 25 \mathrm{~mL})$. The combined washings were added to the orange oil and evaporated using a rotary evaporator yielding a brown sticky solid. The solid was layered with hexane and left in the fridge overnight. The brown solids obtained were washed with water $(4 \times 25 \mathrm{~mL})$ and dried in air $(2.29 \mathrm{~g}, 64 \%$ yield $) .{ }^{1} \mathrm{H} \mathrm{NMR}\left(\mathrm{CDCl}_{3}\right): \delta$ $8.4(\mathrm{~s}, 1 \mathrm{H}), \delta 7.6(\mathrm{~d}, 3 \mathrm{H}), \delta 7.5(\mathrm{~d}, 3 \mathrm{H}), \delta 6.4(\mathrm{dd}, 3 \mathrm{H})[44] . \mathrm{m} / z(\mathrm{ESI}) 237.0\left[(\mathrm{pz})_{3} \mathrm{CH}-\mathrm{Na}\right]^{+} . \tilde{v}_{\max } / \mathrm{cm}^{-1}$ $2985\left(v_{\mathrm{Ar}-\mathrm{H}}\right), 1655\left(v_{\mathrm{C}=\mathrm{N}}\right), 1429\left(v_{\mathrm{C}-\mathrm{H}}\right), 1318,1202\left(v_{\mathrm{C}-\mathrm{N}}\right)$.

For the synthesis of compound 2, tris(pyrazolyl)methane $\left((\mathrm{pz})_{3} \mathrm{CH}\right)(143 \mathrm{mg}, 0.67 \mathrm{mmol})$ was dissolved in a mixed solvent made up from $\mathrm{MeOH}(5 \mathrm{~mL})$ and acetone $(5 \mathrm{~mL}) \cdot \mathrm{Fe}\left(\mathrm{ClO}_{4}\right)_{3} \cdot \mathrm{nH}_{2} \mathrm{O}(180 \mathrm{mg}$, $0.46 \mathrm{mmol}$ ) was added to the mixture which was stirred at ambient temperature for $10 \mathrm{~min}$. A pinkish red solution formed as well as some precipitate. The obtained pink powder was filtered and dried in air $\left(75 \mathrm{mg}, 69 \%\right.$ yield). $\tilde{v}_{\text {max }} / \mathrm{cm}^{-1} 3018\left(v_{\mathrm{Ar}-\mathrm{H}}\right), 1443\left(v_{\mathrm{C}-\mathrm{H}}\right), 1281\left(v_{\mathrm{C}-\mathrm{N}}\right), 1081\left(v_{\mathrm{Cl}-\mathrm{O}}\right) . \mathrm{m} / \mathrm{z}(\mathrm{ESI}) 242.3$ $\left[\mathrm{Fe}^{\mathrm{II}}\left\{(\mathrm{pz})_{3} \mathrm{CH}\right\}\right]^{+}$.

The obtained powder could be crystallised as red block-shaped crystals by diffusing diethyl ether into a saturated solution of the complex dissolved in $\mathrm{CH}_{3} \mathrm{CN}, \mathrm{MeOH}$ and $\mathrm{H}_{2} \mathrm{O}$. See ESI for crystal data.

\subsection{Synthesis of $\left[\mathrm{Fe}^{\mathrm{II}}(\mathrm{TPPZ})_{2}\right]\left[\left(\mathrm{Fe}^{\mathrm{III}} \mathrm{Cl}_{3}\right)_{2} \mathrm{O}\right] \cdot 2 \mathrm{MeCN}, \mathbf{3}$}

$\mathrm{FeCl}_{2} \cdot 4 \mathrm{H}_{2} \mathrm{O}(50 \mathrm{mg}, 0.25 \mathrm{mmol})$ was dissolved in $\mathrm{MeOH}(5 \mathrm{~mL})$ in air. The clear light green solution was stirred for $5 \mathrm{~min}$ and added, dropwise, into the TPPZ ligand (194 mg, $0.50 \mathrm{mmol}$ ) dissolved in $30 \mathrm{~mL}$ of MeCN. The colour suddenly changed into dark purple. After it was continuously stirred for $2.5 \mathrm{hrs}$, the mixture was filtered through paper. The purple filtrate was evaporated down to $50 \%$ volume by rotary evaporation. Some of the residual filtrate was diffused in diethyl ether to yield red block crystals of $\mathbf{3}$ suitable for single crystal X-ray diffraction study. The rest of the filtrate was allowed to slowly evaporate under ambient conditions and gave rise to a dark purple microcrystalline product $(71 \mathrm{mg}, 68 \%)$ which was used for double salt attempted syntheses. $\tilde{U}_{\max } / \mathrm{cm}^{-1} 3050\left(v_{\mathrm{Ar}-\mathrm{H}}\right)$, 1587, $1561\left(v_{\mathrm{C}=\mathrm{N}}\right), 1534\left(v_{\mathrm{C}=\mathrm{C}}\right), 1242\left(v_{\mathrm{C}-\mathrm{N}}\right) . \mathrm{m} / z(\mathrm{ESI}) 867.2\left[\mathrm{Fe}^{\mathrm{II}}\left(\mathrm{TPPZ}_{2}\right]_{\mathrm{Cl}^{+}}\right.$and $416.1\left[\mathrm{Fe}^{\mathrm{II}}(\mathrm{TPPZ})\right]^{+}$. Unfortunately, the PXRD pattern in Figure S11 does not agree with the simulated PXRD from the single crystal of 3. 


\subsection{Synthesis of $\left[\mathrm{Fe}^{\mathrm{II}}\left\{(\mathrm{pz})_{3} \mathrm{CH}_{2}\right]\left[\mathrm{Fe}^{I I I}(a z p)_{2}\right]_{2} \cdot 2 \mathrm{H}_{2} \mathrm{O}, 4\right.$}

Compound 1 ( $21 \mathrm{mg}, 34 \mu \mathrm{mol})$ and compound $2(13 \mathrm{mg}, 19 \mu \mathrm{mol})$ were dissolved in a mixture of dimethylformamide $(2 \mathrm{~mL})$ and water $(2 \mathrm{~mL})$, and heated at $85{ }^{\circ} \mathrm{C}$ in a sealed vial for $72 \mathrm{~h}$ during which time a black crystalline product formed that was suitable for X-ray diffraction studies. Unfortunately, despite repeated attempts, we could not get sufficient pure bulk samples to do magnetic studies (PXRD pattern shown in Figure S11).

\subsection{Synthesis of $\left[\mathrm{Fe}^{\mathrm{II}}(\mathrm{TPPZ})_{2}\right]\left[\mathrm{Fe} \mathrm{eII}^{\mathrm{II}}(\mathrm{azp})_{2}\right]_{2} \cdot \mathrm{H}_{2} \mathrm{O}, \mathbf{5}$}

Compound 1 (13 mg, $21 \mu \mathrm{mol})$ and compound $3(13 \mathrm{mg}, 10 \mu \mathrm{mol})$ were dissolved in a mixture of dimethylformamide $(1 \mathrm{~mL})$ and water $(3 \mathrm{~mL})$, and heated at $90{ }^{\circ} \mathrm{C}$ in a sealed vial for 5 days during which time a black crystalline product formed that was suitable for X-ray determination. Unfortunately, we could not get sufficient pure bulk samples to do magnetic studies. The PXRD for 5 did not match that simulated from the crystal structure (see Figure S10)

\subsection{Synthesis of $\left[\mathrm{Fe}^{\mathrm{II}}(\mathrm{TPPZ})_{2}\right]\left[\mathrm{Fe} \mathrm{III}^{\mathrm{II}}(\mathrm{azp})_{2}\right]_{2} \cdot \mathrm{H}_{2} \mathrm{O} \cdot 3 \mathrm{MeCN}, \mathbf{6}$}

Compound 5 was dissolved in $\mathrm{MeCN}$ and stirred for $15 \mathrm{~min}$. After filtering, the filtrate was allowed to slowly evaporate under ambient conditions for 2 weeks. A black microcrystalline product was obtained suitable for X-ray crystallographic analysis. $\tilde{v}_{\max } / \mathrm{cm}^{-1} 3050\left(v_{\mathrm{Ar}-\mathrm{H}}\right), 1670\left(v_{\mathrm{C}=\mathrm{N}}\right), 1582$ $\left(v_{\mathrm{C}=\mathrm{N}}\right), 1534\left(v_{\mathrm{C}=\mathrm{C}}\right), 1238\left(v_{\mathrm{C}-\mathrm{N}}\right)$. Microanalysis on a bulk sample that had been left in air for months suggested the absorption of water occurred with the concomitant loss of some MeCN solvate. Calcd. For $\left[\mathrm{Fe}^{\mathrm{II}}(\mathrm{TPPZ})_{2}\right]\left[\mathrm{Fe}^{\mathrm{III}}(\mathrm{azp})_{2}\right]_{2} \cdot 4 \mathrm{H}_{2} \mathrm{O} \cdot \mathrm{MeCN}$ (found \%) $\mathrm{Fe}_{3} \mathrm{O}_{12} \mathrm{C}_{98} \mathrm{H}_{75} \mathrm{~N}_{21}: \mathrm{C}, 61.74$ (61.64); $\mathrm{H}, 3.97$ (3.73); N, $15.43 \%$ (15.51). m/z (ESI) $480\left[\mathrm{Fe}^{\mathrm{III}}(\mathrm{azp})_{2}\right]^{-}$and 416.1 [Fe $\left.^{\mathrm{II}}(\mathrm{TPPZ})\right]^{+}$. The PXRD of 6 agreed with the pattern simulated from the crystal structure (see Figure S10).

\section{Conclusions}

Structural and magnetic properties of a new family of mixed valent $\mathrm{Fe}^{\mathrm{III}}$ and $\mathrm{Fe}^{\mathrm{II}}$ double salt complexes i.e., $\left[\mathrm{Fe}^{\mathrm{II}}\left\{(\mathrm{pz})_{3} \mathrm{CH}\right\}_{2}\right]\left[\mathrm{Fe}^{\mathrm{III}}(\mathrm{azp})_{2}\right]_{2} \cdot 2 \mathrm{H}_{2} \mathrm{O}(4)$, $\left.\left[\mathrm{Fe}^{\mathrm{II}}(\mathrm{TPPZ})_{2}\right]\left[\mathrm{Fe}^{\mathrm{III}}(\mathrm{azp})_{2}\right]_{2}\right] \cdot \mathrm{H}_{2} \mathrm{O}(5)$ and $\left.\left[\mathrm{Fe}^{\mathrm{II}}(\mathrm{TPPZ})_{2}\right]\left[\mathrm{Fe}^{\mathrm{III}}(\mathrm{azp})_{2}\right]_{2}\right] \cdot \mathrm{H}_{2} \mathrm{O} \cdot 3 \mathrm{MeCN}(6)$ were examined. This is the first time that the $\left[\mathrm{Fe}^{\mathrm{III}}(\mathrm{azp})_{2}\right]^{-}$ spin crossover compound has been used as an anionic component in such double salts complexes. Single crystal structures of 5-6 at $100 \mathrm{~K}$ revealed a combination of $1 \mathrm{HS}-\mathrm{Fe}^{\mathrm{III}}$ : $1 \mathrm{LS}-\mathrm{Fe} \mathrm{e}^{\mathrm{III}}$ : $1 \mathrm{LS}-\mathrm{Fe}^{\mathrm{II}}$. Compound 6 shows incomplete spin crossover up to $360 \mathrm{~K}$ relating to the spin transition at the $\mathrm{Fe}^{\mathrm{III}}$ centres. The structures of compounds 4 and 5 are constructed from anionic sheets of $\left[\mathrm{Fe}^{\mathrm{III}}(\mathrm{azp})_{2}\right]^{-}$with cationic $\mathrm{Fe}^{\mathrm{II}}$ molecules occupying positions between the layers which are similar to other previously reported mixed-valent $\mathrm{Fe}^{\mathrm{II}} / \mathrm{Fe}^{\mathrm{III}}$ complexes [17-19,41]. Interestingly, compound 6, which has extra $\mathrm{MeCN}$ molecules in the crystal lattice, shows a unique packing with a combination of all metal centres linking in the same pseudo-1D chain. The difference in crystal packing of 5 and $\mathbf{6}$ clearly shows solvent effects are important in molecular structure of these double salt materials.

When making comparisons between the structures of the starter materials 1-3 and the double salt products 4-6, the characters (such as crystal packing, intermolecular interactions with neighbouring molecules and orientation of the ligands) of the cationic $\mathrm{Fe}^{\mathrm{II}}$ molecules i.e., $\left[\mathrm{Fe}^{\mathrm{II}}\left\{(\mathrm{pz})_{3} \mathrm{CH}\right\}_{2}\right]^{2+}$ and $\left[\mathrm{Fe}^{\mathrm{II}}(\mathrm{TPPZ})_{2}\right]^{2+}$, are similar to what they are in the precursor compounds. On the other hand, the packing and spin states of the anionic $\left[\mathrm{Fe}^{\mathrm{III}}(\mathrm{azp})_{2}\right]^{-}$species are varied. It mainly depends on size and functional groups of the cationic counterion molecules.

This present study is the beginning of the investigations of ionic double salts in spin crossover materials. Although, complete spin crossover was not observed in this current work, we believe that mixed valent $\mathrm{Fe}^{\mathrm{III}} / \mathrm{Fe}^{\mathrm{II}}$ systems can give rise to novel compounds with unprecedented magnetic properties. Further examples of new combinations of spin crossover components will be described in future work. 
Supplementary Materials: The following are available online at http://www.mdpi.com/2312-7481/5/2/37/s1, Figures S1-S9: Crystal packing illustrations, Figures S10 and S11: PXRD data, Tables S1-S7: Structural data.

Author Contributions: The experimental work was performed mainly by W.P. and assisted by D.S.M., B.A.I.L. and D.F.W. The single crystal X-ray diffractions and magnetic measurements were made by W.P. K.S.M. supported the work and supervised the experimental work. The manuscript was written by W.P. and K.S.M. All authors have given approval for the final version of the manuscript.

Funding: This work was supported by an Australian Research Council Discovery grant to K.S.M.

Acknowledgments: Part of this work was conducted using the MX1 beamline at the Australian Synchrotron, which is part of ANSTO [42]. The authors acknowledge use of facilities within the Monash X-ray Platform.

Conflicts of Interest: The authors declare no conflict of interest.

\section{References}

1. Harding, D.J.; Harding, P.; Phonsri, W. Spin crossover in iron(III) complexes. Coord. Chem. Rev. 2016, 313, 38-61. [CrossRef]

2. Harding, D.J.; Phonsri, W.; Harding, P.; Murray, K.S.; Moubaraki, B.; Jameson, G.N.L. Abrupt two-step and symmetry breaking spin crossover in an iron(III) complex: An exceptionally wide [LS-HS] plateau. Dalton Trans. 2015, 44, 15079-15082. [CrossRef] [PubMed]

3. Gütlich, P.; Garcia, Y.; Goodwin, H.A. Spin crossover phenomena in Fe(II) complexes. Chem. Soc. Rev. 2000, 29, 419-427. [CrossRef]

4. Gütlich, P.; Goodwin, H.A. (Eds.) Spin Crossover in Transition Metal Compounds I-III; Springer: Berlin/Heidelberg, Germany, 2004; Volumes 232-235.

5. Floquet, S.; Guillou, N.; Negrier, P.; Riviere, E.; Boillot, M.-L. The crystallographic phase transition for a ferric thiosemicarbazone spin crossover complex studied by X-ray powder diffraction. New J. Chem. 2006, 30, 1621-1627. [CrossRef]

6. Zelentsov, V.V.; Bogdanova, L.G.; Ablov, A.V.; Gerbeleu, N.V.; Dyatlova, C.V. Russ J. Inorg. Chem. (Engl. Trans.) 1973, 18, 1410.

7. Li, Z.-Y.; Dai, J.-W.; Shiota, Y.; Yoshizawa, K.; Kanegawa, S.; Sato, O. Multi-step spin crossover accompanied by symmetry breaking in an Fe ${ }^{\mathrm{III}}$ complex: Crystallographic evidence and dft studies. Chem. Eur. J. 2013, 19, 12948-12952. [CrossRef] [PubMed]

8. Murata, S.; Takahashi, K.; Sakurai, T.; Ohta, H.; Yamamoto, T.; Einaga, Y.; Shiota, Y.; Yoshizawa, K. The role of coulomb interactions for spin crossover behaviors and crystal structural transformation in novel anionic $\mathrm{Fe}(\mathrm{III})$ complexes from a $\pi$-extended ONO ligand. Crystals 2016, 6, 49. [CrossRef]

9. Takahashi, K.; Kawamukai, K.; Okai, M.; Mochida, T.; Sakurai, T.; Ohta, H.; Yamamoto, T.; Einaga, Y.; Shiota, Y.; Yoshizawa, K. A new family of anionic Fe ${ }^{\mathrm{III}}$ spin crossover complexes featuring a weak-field $\mathrm{N}_{2} \mathrm{O}_{4}$ coordination octahedron. Chem. Eur. J. 2016, 22, 1253-1257. [CrossRef]

10. Kazuyuki, T.; HengBo, C.; Hayao, K.; Yasuaki, E.; Osamu, S. The light-induced excited spin state trapping effect on $\mathrm{Ni}(\mathrm{dmit})_{2}$ salt with an $\mathrm{Fe}(\mathrm{III})$ spin-crossover cation: $\left[\mathrm{Fe}(\mathrm{qsal})_{2}\right]\left[\mathrm{Ni}(\mathrm{dmit})_{2}\right] \cdot 2 \mathrm{CH}_{3} \mathrm{CN}$. Chem. Lett. 2005, 34, 1240-1241.

11. Vieira, B.J.C.; Coutinho, J.T.; Dias, J.C.; Nunes, J.C.; Santos, I.C.; Pereira, L.C.J.; da Gama, V.; Waerenborgh, J.C. Crystal structure and spin crossover behavior of the $\left[\mathrm{Fe}(5-\mathrm{Cl}-\mathrm{qsal})_{2}\right]\left[\mathrm{Ni}(\mathrm{dmit})_{2}\right] \cdot 2 \mathrm{CH}_{3} \mathrm{CN}$ complex. Polyhedron 2015, 85, 643-651. [CrossRef]

12. Faulmann, C.; Dorbes, S.; Lampert, S.; Jacob, K.; Garreau de Bonneval, B.; Molnár, G.; Bousseksou, A.; Real, J.A.; Valade, L. Crystal structure, magnetic properties and mössbauer studies of [Fe(qsal $\left.)_{2}\right]\left[\mathrm{Ni}(\mathrm{dmit})_{2}\right]$. Inorg. Chim. Acta 2007, 360, 3870-3878. [CrossRef]

13. Takahashi, K.; Sakurai, T.; Zhang, W.-M.; Okubo, S.; Ohta, H.; Yamamoto, T.; Einaga, Y.; Mori, H. Spin-singlet transition in the magnetic hybrid compound from a spin-crossover Fe(III) cation and $\pi$-radical anion. Inorganics 2017, 5, 54. [CrossRef] 
14. Murray, K.S.; Fallon, G.D.; Hockless, D.C.R.; Lu, K.D.; Moubaraki, B.; Van Langenberg, K. Molecular magnetic materials and small clusters containing $n$-donor chelated metal species combined with hexacyanometallate, tris-oxalatometallate, and related bridging groups. In Molecule-Based Magnetic Materials; Turnbull, M.M., Sugimoto, T., Thompson, L.K., Eds.; American Chemical Society: Washington, DC, USA, 1996; Volume 644, pp. 201-215.

15. Kuramochi, S.; Shiga, T.; Cameron, J.M.; Newton, G.N.; Oshio, H. Synthesis, crystal structures and magnetic properties of composites incorporating an $\mathrm{Fe}(\mathrm{II})$ spin crossover complex and polyoxometalates. Inorganics 2017, 5, 48. [CrossRef]

16. Phonsri, W.; Davies, C.G.; Jameson, G.N.L.; Moubaraki, B.; Murray, K.S. Spin crossover, polymorphism and porosity to liquid solvent in heteroleptic iron(III) \{quinolylsalicylaldimine/thiosemicarbazone-salicylaldimine\} complexes. Chem. Eur. J. 2016, 22, 1322-1333. [CrossRef]

17. Sunatsuki, Y.; Ikuta, Y.; Matsumoto, N.; Ohta, H.; Kojima, M.; Iijima, S.; Hayami, S.; Maeda, Y.; Kaizaki, S.; Dahan, F.; et al. An unprecedented homochiral mixed-valence spin-crossover compound. Angew. Chem. Int. Ed. 2003, 42, 1614-1618. [CrossRef] [PubMed]

18. Uhrecký, R.; Svoboda, I.; Růžičková, Z.; Koman, M.; Dlháň, L'.; Pavlik, J.; Moncol, J.; Boča, R. Synthesis, structure and magnetism of manganese and iron dipicolinates with $\mathrm{N}, \mathrm{N}^{\prime}$-donor ligands. Inorg. Chim. Acta 2015, 425, 134-144. [CrossRef]

19. Aghabozorg, H.; Mohamad Panah, F.; Sadr-Khanlou, E. Crystal structure of $\left[\mathrm{Fe}(\mathrm{bpy})_{3}\right]\left[\mathrm{Fe}(\mathrm{pydc})_{2}\right]_{2}\left(\mathrm{pydch}_{2}\right)_{1 / 2}$ $6.5 \mathrm{H}_{2} \mathrm{O}$ complex (bpy $=2,2^{\prime}$-bipyridine, pydc $=$ pyridine-2,6-dicarboxylate). Anal. Sci. X-ray Struct. Anal. Online 2007, 23, x139-x140. [CrossRef]

20. Laine, P.; Gourdon, A.; Launay, J.P. Chemistry of iron with dipicolinic acid. 4. Mixed-ligand complexes of iron(III) and related compounds. Inorg. Chem. 1995, 34, 5156-5165. [CrossRef]

21. Sunatsuki, Y.; Ohta, H.; Kojima, M.; Ikuta, Y.; Goto, Y.; Matsumoto, N.; Iijima, S.; Akashi, H.; Kaizaki, S.; Dahan, F.; et al. Supramolecular spin-crossover iron complexes based on imidazole-imidazolate hydrogen bonds. Inorg. Chem. 2004, 43, 4154-4171. [CrossRef]

22. Brewer, C.T.; Brewer, G.; Butcher, R.J.; Carpenter, E.E.; Schmiedekamp, A.M.; Schmiedekamp, C.; Straka, A.; Viragh, C.; Yuzefpolskiy, Y.; Zavalij, P. Synthesis and characterization of homo- and heterodinuclear $\mathrm{M}(\mathrm{II})-\mathrm{M}^{\prime}(\mathrm{III})\left(\mathrm{M}(\mathrm{II})=\mathrm{Mn}\right.$ or Fe, $\mathrm{M}^{\prime}(\mathrm{III})=\mathrm{Fe}$ or $\left.\mathrm{Co}\right)$ mixed-valence supramolecular pseudo-dimers. The effect of hydrogen bonding on spin state selection of M(II). Dalton Trans. 2011, 40, 181-194. [CrossRef]

23. Ikuta, Y.; Ooidemizu, M.; Yamahata, Y.; Yamada, M.; Osa, S.; Matsumoto, N.; Iijima, S.; Sunatsuki, Y.; Kojima, M.; Dahan, F.; et al. A new family of spin crossover complexes with a tripod ligand containing three imidazoles: Synthesis, characterization, and magnetic properties of $\left[\mathrm{Fe}^{\mathrm{II}} \mathrm{H}_{3} \mathrm{LMe}\right]\left(\mathrm{NO}_{3}\right)_{2} \cdot 1.5 \mathrm{H}_{2} \mathrm{O}$, $\left[\mathrm{Fe}{ }^{\mathrm{III}} \mathrm{LMe}\right] \cdot 3.5 \mathrm{H}_{2} \mathrm{O}, \quad\left[\mathrm{Fe}^{\mathrm{II}} \mathrm{H}_{3} \mathrm{LMe}\right]\left[\mathrm{Fe}^{\mathrm{II}} \mathrm{LMe} \mathrm{NO}_{3}, \quad\right.$ and $\quad\left[\mathrm{Fe}^{\mathrm{II}} \mathrm{H}_{3} \mathrm{LMe}\right]\left[\mathrm{Fe}{ }^{\mathrm{III}} \mathrm{LMe}\right]\left(\mathrm{NO}_{3}\right)_{2} \quad\left(\mathrm{H}_{3} \mathrm{LMe}=\right.$ tris[2-(((2-methylimidazol-4-yl)methylidene)amino)ethyl]amine). Inorg. Chem. 2003, 42, 7001-7017. [PubMed]

24. Brewer, C.T.; Brewer, G.; Butcher, R.J.; Carpenter, E.E.; Schmiedekamp, A.M.; Viragh, C. Synthesis and characterization of a spin crossover iron(II)-iron(III) mixed valence supramolecular pseudo-dimer exhibiting chiral recognition, hydrogen bonding, and $\pi-\pi$ interactions. Dalton Trans. 2007, 295-298. [CrossRef] [PubMed]

25. Lavrenova, L.G. Spin crossover in homo- and heteroligand iron(II) complexes with tris (pyrazol-1-y1)methane derivates. Russ. Chem. Bull. Int. Ed. 2018, 67, 1142-1152. [CrossRef]

26. Paulsen, H.; Duelund, L.; Zimmermann, A.; Averseng, F.; Gerdan, M.; Winkler, H.; Toftlund, H.; Trautwein, A.X. Substituent effects on the spin-transition temperature in complexes with tris(pyrazolyl) ligands. Monatsh. Chem. 2003, 134, 295-306. [CrossRef]

27. McGarvey, J.J.; Toftlund, H.; Al-Obaidi, A.H.R.; Taylor, K.P.; Bell, S.E.J. Photoperturbation of the ${ }^{1} \mathrm{~A} \rightarrow{ }^{5} \mathrm{~T}$ spin equilibrium in an iron(II) complex in solution via ligand field excitation. Inorg. Chem. 1993, 32, 2469-2472. [CrossRef]

28. Anderson, P.A.; Astley, T.; Hitchman, M.A.; Keene, F.R.; Moubaraki, B.; Murray, K.S.; Skelton, B.W.; Tiekink, E.R.T.; Toftlund, H.; White, A.H. Structures and spectra of bis-tripodal iron(II) chelates, $\left[\mathrm{FeL}_{2}\right]^{2+}$, where $\mathrm{L}=$ tris(pyrazol-1-yl)methane, tris(pyridin-2-yl)methane, bis(pyrazol-1-yl)(pyridin-2-yl)methane and tris(pyridin-2-yl)phosphine oxide. Magnetism and spin crossover in the (pz) ${ }_{3} \mathrm{CH}$ case. J. Chem. Soc. Dalton Trans. 2000, 3505-3512. 
29. Reger, D.L.; Little, C.A.; Rheingold, A.L.; Lam, M.; Liable-Sands, L.M.; Rhagitan, B.; Concolino, T.; Mohan, A.; Long, G.J.; Briois, V.; et al. A synthetic, structural, magnetic, and spectral study of several $\left\{\mathrm{Fe}[\text { tris(pyrazolyl)methane }]_{2}\right\}\left(\mathrm{BF}_{4}\right)_{2}$ complexes: Observation of an unusual spin-state crossover. Inorg. Chem. 2001, 40, 1508-1520. [CrossRef]

30. Campos-Fernández, C.S.; Smucker, B.W.; Clérac, R.; Dunbar, K.R. Reactivity studies of 2,3,5,6-tetra(2-pyridyl) pyrazine (tppz) with first-row transition metal ions. Isr. J. Chem. 2001, 41, 207-218. [CrossRef]

31. Toma, L.M.; Armentano, D.; De Munno, G.; Sletten, J.; Lloret, F.; Julve, M. 2,3,5,6-tetrakis(2-pyridyl)pyrazine (tppz)-containing iron(II) complexes: Syntheses and crystal structures. Polyhedron 2007, 26, 5263-5270. [CrossRef]

32. Halcrow, M.A. The synthesis and coordination chemistry of 2,6-bis(pyrazolyl)pyridines and related ligands-Versatile terpyridine analogues. Coord. Chem. Rev. 2005, 249, 2880-2908. [CrossRef]

33. Pritchard, R.; Kilner, C.A.; Halcrow, M.A. Iron(II) complexes with a terpyridine embrace packing motif show remarkably consistent cooperative spin-transitions. Chem. Commun. 2007, 577-579. [CrossRef] [PubMed]

34. McCusker, J.K.; Rheingold, A.L.; Hendrickson, D.N. Variable-temperature studies of laser-initiated ${ }^{5} \mathrm{~T}_{2} \rightarrow{ }^{1} \mathrm{~A}_{1}$ intersystem crossing in spin-crossover complexes: Empirical correlations between activation parameters and ligand structure in a series of polypyridyl ferrous complexes. Inorg. Chem. 1996, 35, 2100-2112. [CrossRef]

35. Marchivie, M.; Guionneau, P.; Letard, J.-F.; Chasseau, D. Photo-induced spin-transition: The role of the iron(II) environment distortion. Acta Crystallogr. Sect. B Struct. Sci. 2005, 61, 25-28. [CrossRef] [PubMed]

36. Abibat Salaudeen, A.; Kilner, C.A.; Halcrow, M.A. Mononuclear and dinuclear iron thiocyanate and selenocyanate complexes of tris-pyrazolylmethane ligands. Polyhedron 2008, 27, 2569-2576. [CrossRef]

37. Haselhorst, G.; Wieghardt, K.; Keller, S.; Schrader, B. The ( $\mu$-oxo)bis[trichloroferrate(III)] dianion revisited. Inorg. Chem. 1993, 32, 520-525. [CrossRef]

38. Padgett, C.W.; Pennington, W.T.; Hanks, T.W. Conformations and binding modes of 2,3,5,6-tetra(2'-pyridyl)pyrazine. Cryst. Growth Des. 2005, 5, 737-744. [CrossRef]

39. Behnamfar, M.T.; Hadadzadeh, H.; Simpson, J.; Darabi, F.; Shahpiri, A.; Khayamian, T.; Ebrahimi, M.; Amiri Rudbari, H.; Salimi, M. Experimental and molecular modeling studies of the interaction of the polypyridyl Fe(II) and Fe(III) complexes with DNA and bsa. Spectrochim. Acta Part A 2015, 134, 502-516. [CrossRef] [PubMed]

40. Russell, V.; Scudder, M.; Dance, I. The crystal supramolecularity of metal phenanthroline complexes. J. Chem. Soc. Dalton Trans. 2001, 789-799. [CrossRef]

41. Hu, X.; Guo, J.; Wang, Y.; Liu, C. Synthesis, infrared spectra, thermal analyses and structural studies of half-sandwich $\mathrm{Fe}(\mathrm{III}) / \mathrm{Fe}(\mathrm{II})$ complex containing pyridine-2,6-dicarboxylate and 1,10-phenanthroline. Spectrochim. Acta Part A 2009, 74, 48-51. [CrossRef] [PubMed]

42. McPhillips, T.M.; McPhillips, S.E.; Chiu, H.-J.; Cohen, A.E.; Deacon, A.M.; Ellis, P.J.; Garman, E.; Gonzalez, A.; Sauter, N.K.; Phizackerley, R.P.; et al. Blu-ice and the distributed control system: Software for data acquisition and instrument control at macromolecular crystallography beamlines. J. Synchrotron Radiat. 2002, 9, 401-406. [CrossRef]

43. Kabsch, W. Automatic processing of rotation diffraction data from crystals of initially unknown symmetry and cell constants. J. Appl. Crystallogr. 1993, 26, 795-800. [CrossRef]

44. Langenberg, K.V. Molecular-Based Magnetic Materials Incorporating Bis-and Tris(pyrazolyl)methane transition Metal Complexes. Hons. B.Sc. Honours Thesis, Monash University, Melbourne, Australia, 1993.

45. Cowieson, N.P.; Aragao, D.; Clift, M.; Ericsson, D.J.; Gee, C.; Harrop, S.J.; Mudie, N.; Panjikar, S.; Price, J.R.; Riboldi-Tunnicliffe, A.; et al. Mx1: A bending-magnet crystallography beamline serving both chemical and macromolecular crystallography communities at the australian synchrotron. J. Synchrotron Radiat. 2015, 22, 187-190. [CrossRef]

(C) 2019 by the authors. Licensee MDPI, Basel, Switzerland. This article is an open access article distributed under the terms and conditions of the Creative Commons Attribution (CC BY) license (http://creativecommons.org/licenses/by/4.0/). 